\title{
The Function of Neurotrophic Factor Receptors Expressed by the Developing Adductor Motor Pool In Vivo
}

\author{
Thomas W. Gould and Ronald W. Oppenheim \\ Department of Neurobiology and Anatomy and Neuroscience Program, Wake Forest University School of Medicine, Winston-Salem, North Carolina 27157
}

We examined the spatio-temporal relationship between neurotrophic factor receptor (NTF-R) expression and motoneuron (MN) survival in the developing avian spinal cord and observed heterogeneity in the expression of NTF-Rs between, but not within, pools of MNs projecting to individual muscles. We then focused on the role of NTFs in regulating the survival of one motor pool of MNs, all of which innervate a pair of adductor muscles in the thigh and hence compete for survival during the period of programmed cell death (PCD). The complete NTF-R complement of these MNs was analyzed and found to include many, but not all, NTF-Rs. Treatment with exogenous individual NTFs rescued some, but not all, adductor MNs expressing appropriate NTF-Rs. In contrast, administration of multiple NTFs completely rescued adductor MNs from PCD. Additionally, adductor MNs were partially rescued from PCD by NTFs for which they failed to express receptors. NTF-Rs expressed by the nerve but not in the muscle target were capable of mediating survival signals to MNs in trans. Finally, the expression of some NTF-Rs by adductor MNs was not required for MN survival. These studies demonstrate the complexity in NTF regulation of a defined subset of competing MNs and suggest that properties other than NTF-R expression itself can play a role in mediating trophic responses to NTFs.

Key words: motor pool; motoneurons; trophic receptor; cell death; spinal cord; innervation

\section{Introduction}

In the chick embryo, the number of postmitotic spinal motoneurons (MNs) is reduced by approximately one-half during the process of developmental programmed cell death (PCD) (Hamburger, 1975). This elimination of differentiating, synapseforming MNs appears to reflect in large part a competition for limiting amounts of skeletal muscle-derived neurotrophic factors (NTFs) (Hollyday and Hamburger, 1976; Pittman and Oppenheim, 1979; Phelan and Hollyday, 1991; Grieshammer et al., 1998). Despite the discovery of a large number of survivalpromoting NTFs expressed by muscle and other cell types during the period of MN PCD, the addition or overexpression of any one or a combination of these agents in vivo fails to rescue all spinal MNs originally destined to die (Oppenheim et al., 1993; Zurn et al. 1996; Nguyen et al. 1998). Conversely, elimination of any one NTF, or the receptor through which it acts, fails to eliminate $>40 \%$ of spinal MNs originally destined to live (Henderson, 1996; Oppenheim, 1996). These findings, together with data describing spatial- and temporal-specific patterns of NTF receptors (NTF-Rs) (McKay et al., 1996; Yamamoto et al., 1997; Novak et al., 2000; Garcés et al., 2000, 2001; Homma et al., 2003), suggest that spinal and cranial MNs are heterogeneous in their trophic responsivity. Additionally, NTF-Rs expressed in cell types inti-

Received Aug. 25, 2003; revised April 6, 2004; accepted April 6, 2004.

This work was supported by National Institutes of Health Grant NS20402 to R.W.0. and by a grant from the Robert Packard Center for Amyotrophic Lateral Sclerosis research at Johns Hopkins University (Baltimore, MD). We thank Lynn Landmesser, Robert Oakley, and Woong Sun for technical advice.

Correspondence should be addressed to Dr. Ronald W. Oppenheim, Department of Neurobiology and Anatomy, Wake Forest University School of Medicine, Winston-Salem, NC 27157. E-mail: roppenhm@wfubmc.edu.

DOI:10.1523/JNEUROSCI.0580-04.2004

Copyright $\odot 2004$ Society for Neuroscience $\quad$ 0270-6474/04/244668-15\$15.00/0 mately associated with MNs during development (e.g., Schwann cells) are capable of signaling in trans to MNs, suggesting an additional level of complexity in the regulation of MN survival (Paratcha et al., 2001; Ledda et al., 2002).

The fact that not all MNs respond to increased or reduced NTF availability may simply reflect a difference in expression patterns of specific NTF-Rs. Alternatively, a simultaneously active death-promoting pathway may predominate over those initiated by even excess amounts of individual or multiple NTFs (Raoul et al., 1999, Krieglstein et al., 2000). In this model, treatment with excess NTF would not be sufficient to rescue all MNs expressing appropriate NTF-Rs. Still another alternative is that NTF-R stimulation regulates aspects of $\mathrm{MN}$ development other than survival, such as phenotypic identity, differentiation (e.g., target innervation), or migration of subtypes of MNs (Haase et al., 2002) and is, therefore, neither necessary nor sufficient for the survival of at least some MNs.

To determine whether MN responses to NTFs are predisposed solely by their complement of NTF-Rs, we examined expression patterns of specific NTF-Rs. Because MNs projecting to individual muscle targets are arranged into specific spatial clusters called motor pools even before the period of MN PCD (Landmesser, 1978; Hollyday, 1980), we related NTF-R expression patterns to some of these MN subpopulations. In this study, we concentrated on MNs innervating the adductor muscles in the avian thigh. MNs within this pool are homogeneous in their expression of various NTF-Rs. Therefore, we were able to determine whether NTF-R expression, in the presence of excess, physiological, or reduced amounts of NTF, was necessary or sufficient for MN survival. 


\section{Materials and Methods}

Animals. White leghorn chicken embryos (Tyson, Wilkesboro, NC) were incubated until the appropriate stage (Hamburger and Hamilton, 1951). Their spinal columns were dissected, fixed overnight at $4^{\circ} \mathrm{C}$ in freshly made $4 \%$ paraformaldehyde in $0.1 \mathrm{M}$ PBS, pH 7.4, rinsed in PBS, embedded in 30\% sucrose-PBS, and snap-frozen in 3:2 30\% sucrose-PBS to optimal cutting temperature (OCT) compound (Tissue-Tek; Pelco International, Redding, CA).

Immunohistochemistry. Slides were blocked in 10\% FBS or 10\% NGS for $1 \mathrm{hr}$ at room temperature. The monoclonal antibody supernatants used were anti-TuJ1 (1:500; Boehringer Mannheim, Indianapolis, IN), anti-islet1/2 (39.4D5), anti-1E8 (avian Protein Zero, P0; a Schwann cell marker), anti-MF20 (a skeletal muscle marker; sarcomeric myosin), antiB3/D6 (avian fibronectin), and anti-SV2 (a synaptic vesicle marker), all used at 1:100 to 1:50 and obtained from the Developmental Studies Hybridoma Bank (University of Iowa, Iowa City, IA). Mouse anti-islet1 (1:100) was kindly provided by S. Morton (Columbia University, New York, NY); rabbit anti-chicken CNTFR $\alpha$ (1:1000) was kindly provided by H. Rohrer (Max-Planck-Institut für Hirnforschung, Frankfurt am Main, Germany); rabbit anti-chicken tyrosine kinase B (TrkB) (1:10,000) and rabbit anti-chicken TrkC (1:1000) were kindly provided by F. Lefcort (University of Montana, Bozeman, MT); and rabbit anti-cRet (1:200) was obtained from Santa Cruz Biotechnology (Santa Cruz, CA). Sections were incubated in primary antibody overnight at $4^{\circ} \mathrm{C}$ in $0.03 \%$ Triton- $\mathrm{X}$ and $10 \%$ FBS or NGS. Slides were rinsed in $0.1 \mathrm{~m}$ PBS three times for 5 min and incubated in 1:250 Cy2, Cy3, or Cy5 donkey anti-mouse, donkey anti-rabbit, donkey anti-goat, or goat anti-mouse (Jackson Immunoresearch, West Grove, PA) for $45 \mathrm{~min}$ at room temperature, rinsed, and mounted in Gelmount (Biomeda, Foster City, CA).

Immunoblotting. Rabbit anti-neurturin (NTN) was used at 1:500 (Peprotech, Rocky Hill, NJ); rabbit anti-glial cell line-derived neurotrophic factor (GDNF) was used at 1:100 (D-20; Santa Cruz Biotechnology). Individual muscles were dissected from hindlimbs, stripped carefully of skin and connective tissue, and collected into protein lysis buffer $(20 \mathrm{~mm}$ Tris-HCl, pH 7.5, 10 mм EDTA, 120 mм Nacl, 1\% NP-40, 1 mм NaVO and $1 \times$ protease inhibitor mixture; Sigma, St. Louis, MO). Lysates were cleared, protein concentration was determined, and $100 \mu \mathrm{g}$ of protein was loaded onto $12 \%$ polyacrylamide gels. After transfer to polyvinylidene difluoride membrane (NEN Life Sciences, Boston MA), proteins were stained with $0.1 \%$ India ink to ensure equal loading, rinsed in $1 \times$ TBST ( $0.1 \%$ Tween), blocked in 3\% BSA (Fraction V, IgG free; Sigma)/ TBST for $3 \mathrm{hr}$, and rotated overnight at $4^{\circ} \mathrm{C}$ in primary antibody/BSA. Membranes were rinsed three times for $10 \mathrm{~min}$ in BSA-TBST, incubated in 1:5000 peroxidase-conjugated donkey anti-rabbit, rinsed in TBST five times for $5 \mathrm{~min}$, and detected with Supersignal West Pico chemiluminescent substrate (Pierce, Rockford, IL).

ELISA. For quantitation of GDNF protein by ELISA, individual chick thigh muscles at embryonic day (E) 8, entire chick thighs from E6-E15, or thighs from postnatal day (P) 0-P3 wild-type or GDNFoverexpressing mice (MYO-GDNF) (Ngyuen et al., 1998) were dissected free from connective tissue and fat and collected in $200 \mu$ l of nondenaturing lysis buffer, pH 7.4 ( $0.1 \mathrm{~m}$ Tris buffer, $0.9 \% \mathrm{NaCl}, 0.5 \% \mathrm{NP}-40 ; 10$ $\mathrm{mm} \mathrm{NaF}, 1 \mathrm{~mm} \mathrm{NaV}$, and $1 \times$ protease inhibitors; Sigma). Samples were lysed by passage through a 22 gauge syringe, vortexed several minutes, and microcentrifuged for $30 \mathrm{~min}$. Protein quantity from the samples was normalized using the Bio-Rad (Hercules, CA) assay for total protein determination. GDNF protein levels were quantified by using the GDNF $\mathrm{E}_{\mathrm{MAX}}$ ImmunoAssay system (Promega, Madison, WI). One hundred microliters of $10 \mathrm{mg} / \mathrm{ml}$ protein were loaded into each well of a 96-well plate. GDNF levels for P3 wild-type and MYO-GDNF mice were comparable with those of published reports (Nguyen et al., 1998). Because the secondary detection antibody is of a chicken IgY class, control wells were incubated with capture antibody and protein but without the polyclonal GDNF antibody. Absorbances obtained from these wells represent nonspecific binding of the detection antibody to chick protein extract and were thus subtracted from each absorbance obtained in the presence of the polyclonal GDNF antibody. The plate was read at $450 \mathrm{~nm}$.

Retrograde labeling. Embryos at E6, E8, E10, and E12 were dissected in
Tyrode's solution at room temperature, and a ventral laminectomy from the mid-thoracic to sacral spinal cord was performed rapidly. Connective tissue and parts of the pelvic girdle were removed, and the individual muscles were identified by illumination from below, which, by providing visualization of the unique orientation of the myofibers within each muscle, allows one to reliably identify individual muscles (Landmesser, 1978). Specific muscles were injected with a pulled glass filament $(1 \times$ $0.75 \mathrm{~mm}$; A-M Systems, Carlsborg, WA) with 20\% HRP (type VI; Sigma) in Tyrode's solution or Alexa-Fluor 488- and Alexa-Fluor 594conjugated $\beta$-subunit of cholera toxin (used at $1 \mathrm{mg} / \mathrm{ml}$; Molecular Probes, Eugene, OR). After muscle injection, embryos were incubated at $32^{\circ} \mathrm{C}$ in Tyrode's solution containing $95 \%$ oxygen and $5 \% \mathrm{CO}_{2}$ for $5-7 \mathrm{hr}$ and then fixed overnight in $4 \%$ paraformaldehyde (for cell counts or for immunohistochemistry) or snap-frozen in OCT compound (TissueTek) for in situ hybridization. The number of retrogradely labeled MNs was quantified in embryos injected with HRP by incubating $10-\mu \mathrm{m}$-thick sections (cut at $-30^{\circ} \mathrm{C}$ on a cryostat) with $\mathrm{DAB}$ (Vector Laboratories, Burlingame, CA) to visualize the HRP, $10 \mu \mathrm{g} / \mathrm{ml}$ Hoechst 33342 (Sigma) to stain nuclei, and anti-islet $1 / 2$ to label MNs. Cells were counted as retrogradely labeled MNs if they exhibited fluorescent islet $1 / 2$ immunoreactivity and their nuclear membrane was completely within the plane of a section and surrounded by DAB-positive grains. These counts were corroborated by those in which HRP was detected immunohistochemically with an antibody (1:400, goat-anti-HRP; R\&D Systems, Minneapolis, MN).

In situ hybridization. Embryos were dissected at various time points in cold PBS, and spinal columns were removed and snap-frozen in OCT medium. Digoxygenin- or biotin-labeled riboprobes were hybridized at $68^{\circ} \mathrm{C}$ overnight according to Schaeren-Wiemers and Gerfin-Moser (1993). Biotin-labeled probes were amplified using the tyramide signal amplification kit (NEN Life Sciences). After hybridization, slides were rinsed in $0.2 \times$ SSC for $1 \mathrm{hr}$ at $68^{\circ} \mathrm{C}$, rinsed with $0.2 \times$ SSC for $5 \mathrm{~min}$ at room temperature, rinsed in $1 \times \mathrm{TBS}$, blocked with $2 \%$ blocking reagent (NEN Life Sciences) in $1 \times$ TBS at room temperature for $1 \mathrm{hr}$, incubated in 1:1000 streptavidin-HRP in blocking solution for $45 \mathrm{~min}$ at room temperature, and incubated in 1:50 FITC-Tyramide in amplification diluent (NEN Life Sciences) for 30-45 min. For visualization of both retrogradely labeled MNs and mRNA in the same section, Hoechst 33342-stained, retrogradely labeled MNs were captured before hybridization. After hybridization, sections were blocked with 10\% NGS/0.3\% Triton-X, incubated with 1:100 anti-islet1/2, and visualized with a fluorescently labeled secondary antibody. Sections were restained with Hoechst 33342 and mounted. Although faint signals of the original retrogradely labeled MNs were still visible after in situ hybridization, combined images were prepared by correctly realigning marked sections by superimposing old and new Hoechst-stained images in separate channels in Adobe Photoshop (Adobe Systems, San Jose, CA) before capturing the mRNA image. In some cases, islet1/2-positive MNs were identified by immunofluorescence and pasted into the third channel (blue).

Reverse transcription-PCR and primers. Semiquantitative reverse transcription (RT)-PCR was performed by determining the range of the PCR cycle number in which band intensity increased linearly. Within the central part of the curve [ 19 cycles for glyceraldehyde dehydrogenase $($ GAPDH)], serial dilutions of cDNA (all of which were reverse transcribed within the same experiment) were run for different sets of primers to ensure the validity of the selected cycle number. The cycle number was 33 for BDNF with a temperature of annealing at $57^{\circ} \mathrm{C}, 27$ for hepatocyte growth factor (HGF) at $56^{\circ} \mathrm{C}, 27$ for GDNF at $60^{\circ} \mathrm{C}, 25$ for neurotrophin-3 (NT-3) at $56^{\circ} \mathrm{C}$, and 19 for muscle-specific GAPDH at $60^{\circ} \mathrm{C}$. Primers for RT-PCR were: BDNF: $5^{\prime}$-CCTTTTCCTTACTATGGTTA, 3'-TTTTTCTCCGCTGCTGTTAC; GDNF: 5' -ATCTTCCCCAAAAACAGGTG, 3'-GGTGCTCGTCGTCTCGGTGA; growth-promoting activity (GPA): 5'-CCCCACGCCTCAGCCTCTTC, 3'-CTCAGCATCCACCACAGCCA; GAPDH: 5'-AGCGTGACCCCAGCAACATC, 3'CAGCCTTAGCAGCCCCAGTG; HGF: 5'-GACATCCCCCTGTGCTCTGA, 3'-AACTCTTTCCATTGCCACGA; NT-3: 5' -TCTAAGCAGGTGATGGATGT, 3'-ACGCAGGAGGTGTCTATTCT; cRet: 5'-CTACCTCAGCAAGAGCCT, 5 '-ATGCTCTGTGACTGAAAT. Denatur- 
ation was at $94^{\circ} \mathrm{C}$ for $45 \mathrm{sec}$, annealing for 45 seconds, and elongation at $72^{\circ} \mathrm{C}$ for $60 \mathrm{sec}$.

Primers for constructing riboprobes for in situ hybridization were: CNTFR $\alpha$ : 5' -ATCTTCCCCAAAAACAGGTG, 3'-GGTGCTCGTCGTCTCGGTGA; glycoprotein130 (gp130): 5' -CCCAGAGAAGCCCAAAAACT, 3' -AAGAACATTATTAGGAGCAG; p75: 5' -AACCAGACCGTGTGTGAGCC, 3'-TAGACAGGGATGAGGTTGTC; leukemia inhibitory receptor $\beta$ (LIFR $\beta)$ : 5'-GATTGTCAGGGGTTTTTAGA, $3^{\prime}$-GTTCCAGGCATTTGTGTTTG; GDNF receptor (GFR) $\alpha 4$ : 5' CGGCAGTGTATCGCAGGTA， 3' -CAGGCAGTTGGGTTTCTCC. The cMet-containing plasmid was kindly provided by C. Stern (Columbia University, New York, NY), TrkB and TrkC plasmids were provided by T. Large (Millenium Pharmaceuticals, Raleigh, NC), and cRet, GFR $\alpha 1$, and GFR $\alpha 2$ plasmids were from S. Homma (Fukushima Medical University, Fukushima, Japan).

Construct preparation and in ovo electroporation. Full-length primers against the beginning and end of chick $\operatorname{CNTFR} \alpha$, including $5^{\prime}-N o t \mathrm{I}$ and $3^{\prime}$-EcoRI restriction sites, were used to clone this gene from E6 spinal cord RNA into pCMV-IRES1-GFP (Clontech, Palo Alto, CA). Primary transfection of PC12 cells but not chick MNs resulted in transgene expression, so the gene was cut by NotI, blunt-ended and excised with EcoR1 and cloned into appropriate sites in the pMES vector $(\beta$-actin promoter, IRES2-GFP; kindly provided by C. Krull, University of Missouri, Columbia, MO). After primary transfections of chick MNs confirmed transgene expression, the entire CNTFR $\alpha$-IRES2-GFP construct was cloned into the EcoR1 and XbaI sites of the pTRE vector (Clontech). For electroporation, eggs were windowed at stages $15-18$ and injected with a DNA solution containing pTRE-CNTFR $\alpha$-IRES2-GFP and pCMV-TetR $(2.5 \mu \mathrm{g} / \mu \mathrm{l}$ of each plasmid $)$ diluted in $1 \times$ DNA gel-loading dye to visualize injection. Doxycycline $(1 \mathrm{mg} / \mathrm{ml}$; Sigma) was added at daily intervals from E6-E9 to initiate transgene expression.

In vivo blocking experiments. For the experiment examining endogenous NTF inhibition, GDNF, CNTF $(5 \mu \mathrm{g})$, a neutralizing antibody to GDNF (20 $\mu \mathrm{g}$; R\&D Systems), or the CNTFR $\alpha$ antagonist AADH-CNTF (100 $\mu \mathrm{g}$; from A. DiMarco and R. Laufer, Merck, Darmstadt, Germany) (Di Marco et al., 1996) was administered in ovo daily from E6 to E9 or on E6 and E8 (anti-GDNF). Adductor muscles were retrogradely labeled with HRP and counted at E10. For the experiments summarized in Figure $7, B-E$, embryos were windowed at E3, the amniotic sac was opened at E6, and the hindlimbs (thighs) were injected with a pulled pipette attached to a Hamilton syringe at E7 containing $5 \mu \mathrm{g} / \mu \mathrm{l}$ anti-GDNF or 5 $\mu \mathrm{g} / \mu \mathrm{l}$ mouse monoclonal IgG (Sigma) supplemented with $0.5 \mu \mathrm{g} / \mu \mathrm{l}$ Alexa-Fluor 594-conjugated $\beta$-cholera toxin and $0.1 \%$ trypan blue. Healthy embryos were killed on E8, and spinal columns were dissected and fixed in Carnoy's solution, embedded in paraffin and cut at $8 \mu \mathrm{m}$, and stained with thionin. Pyknotic nuclei were counted in every 20th section throughout the lumbar motor column at $600 \times$ (Clarke and Oppenheim, 1995). For visualization of retrogradely labeled MNs after antibody treatment, the spinal columns of other treated embryos were fixed in $4 \%$ paraformaldehyde, embedded in sucrose-OCT, cut at $10 \mu \mathrm{m}$, and stained with anti-islet $1 / 2$ and Hoechst 33342.

\section{Results}

For the purposes of this study, we define NTF-Rs simply as receptors with a stimulation or inhibition that has been demonstrated to result in increased or decreased $\mathrm{MN}$ cell death in vivo, respectively. NTFs and the receptors examined in this study include GDNF (Yan et al., 1993), comprising the receptor tyrosine kinase cRet and the GDNF-receptor 1 (GFR $\alpha 1)$ (Jing et al., 1996; Treanor et al., 1996; Trupp et al., 1996); NTN (Kotzbauer et al., 1996), acting through c-Ret and GFR $\alpha 2$ (Baloh et al., 1997; Klein et al., 1997); persephin (PSP) (Milbrandt et al., 1998), requiring c-Ret and GFR $\alpha 4$ (Thompson et al., 1998; Masure et al., 2000); HGF/scatter factor (Stoker et al., 1987; Nakamura et al., 1989), acting through cMet (Bottaro et al., 1991; Naldini et al., 1991; Weidner et al., 1993); BDNF (Leibrock et al., 1989), acting through TrkB and/or p75 (Rodriguez-Tebar et al., 1990; Klein et al., 1991; Squinto et al., 1991); NT-3 (Hohn et al., 1990; Jones and Reichardt, 1990; Maisonpierre et al., 1990), acting through TrkC (Lamballe et al., 1991); CNTF (Varon et al., 1979), acting through CNTFR $\alpha$ (Ip et al., 1993); and LIFR $\beta /$ gp130 (Davis et al., 1993).

\section{NTF-Rs are expressed in spatially heterogeneous patterns in spinal cord MNs}

Whereas the existence of NTF-R-expressing subtypes within sensory and MN populations is well established ( $\mathrm{Mu}$ et al., 1993; Horton et al., 1998; Mickleas et al., 2000; Oppenheim et al., 2000; Garcés et al., 2001), a more detailed analysis of these patterns and their function in MNs during the period of cell death is lacking (E6-E12 in the chick lumbar spinal cord). We focused on differences in NTF-R expression in the lumbar spinal cord at E8, the peak of MN cell death. An expression study of GDNF family receptors has already been performed in this region (Homma et al., 2003). The expression of cMet was restricted to the medial lumbar lateral motor column (LMC) across the entire rostrocaudal extent, suggesting that only MNs that innervate muscles derived from the ventral premuscle mass are responsive to $\mathrm{HGF}$ (Fig. 1A) (Landmesser et al., 1978; Hollyday, 1980). TrkB and p75 fail to be expressed by MNs in the most lateral region of the LMC in segments LS4-7. Similar to cMet, CNTFR $\alpha$ mRNA is found throughout the medial LMC but it is also detected in specific regions of the lateral LMC. TrkC mRNA is expressed by most, but not all, LMC MNs, whereas mRNAs for LIFR $\beta$, gp 130, IGF receptor type I, and bone morphogenetic factor receptors (BMPR-1A and 1B) are expressed by virtually all lumbar LMC MNs (Fig. $1 A$ and data not shown). These data indicate that individual regions or subpopulations of lumbar MNs express many different NTF-Rs, and second, that these subpopulations express different combinations of NTF-R. These differences may be sufficient, therefore, to explain differences in $\mathrm{MN}$ responses to NTF modulation.

\section{Hindlimb muscles homogeneously express NTFs during the period of MN PCD}

Although differences in NTF-R expression may contribute to the sculpting of MN numbers during the period of cell death, target muscles to which MNs project may also express NTFs differentially, thereby regulating the survival of specific subpopulations of MNs. For example, several, but not all, forelimb muscles in the mouse express GDNF during the process of MN target innervation (Haase et al., 2002). We analyzed the expression of NTF mRNA by semiquantitative RT-PCR in various hindlimb muscles throughout the period of MN cell death. All hindlimb thigh muscles expressed similar amounts of HGF, BDNF, GDNF, and NT-3 mRNA (Fig. $1 \mathrm{~B}$ and data not shown). GPA, a CNTF-related CNTFR $\alpha$-stimulating ligand, was never detected in the hindlimb from E6 to E10 but was expressed by the sciatic nerve starting at E16 (data not shown), consistent with previous observations (Sendtner et al., 1994). We also detected qualitatively similar amounts of GDNF and NTN protein in two different hindlimb muscles at E8 by immunoblot analysis (Fig. 1C). Additionally, quantitative GDNF protein levels, measured by ELISA, were similar in four hindlimb muscles at E8 (Fig. 1C), and all exhibited increasing amounts of GDNF from E6 to E10. We cannot rule out the possibility that the access of NTF protein is differentially spatially restricted within or between specific muscles. However, a homogeneous striated pattern of GDNF immunoreactivity was present in longitudinal sections of all muscles examined (Hashino et al., 2001) (Fig. $1 C$ and data not shown). Furthermore, GDNF immunoreactivity appeared similar in all muscle 

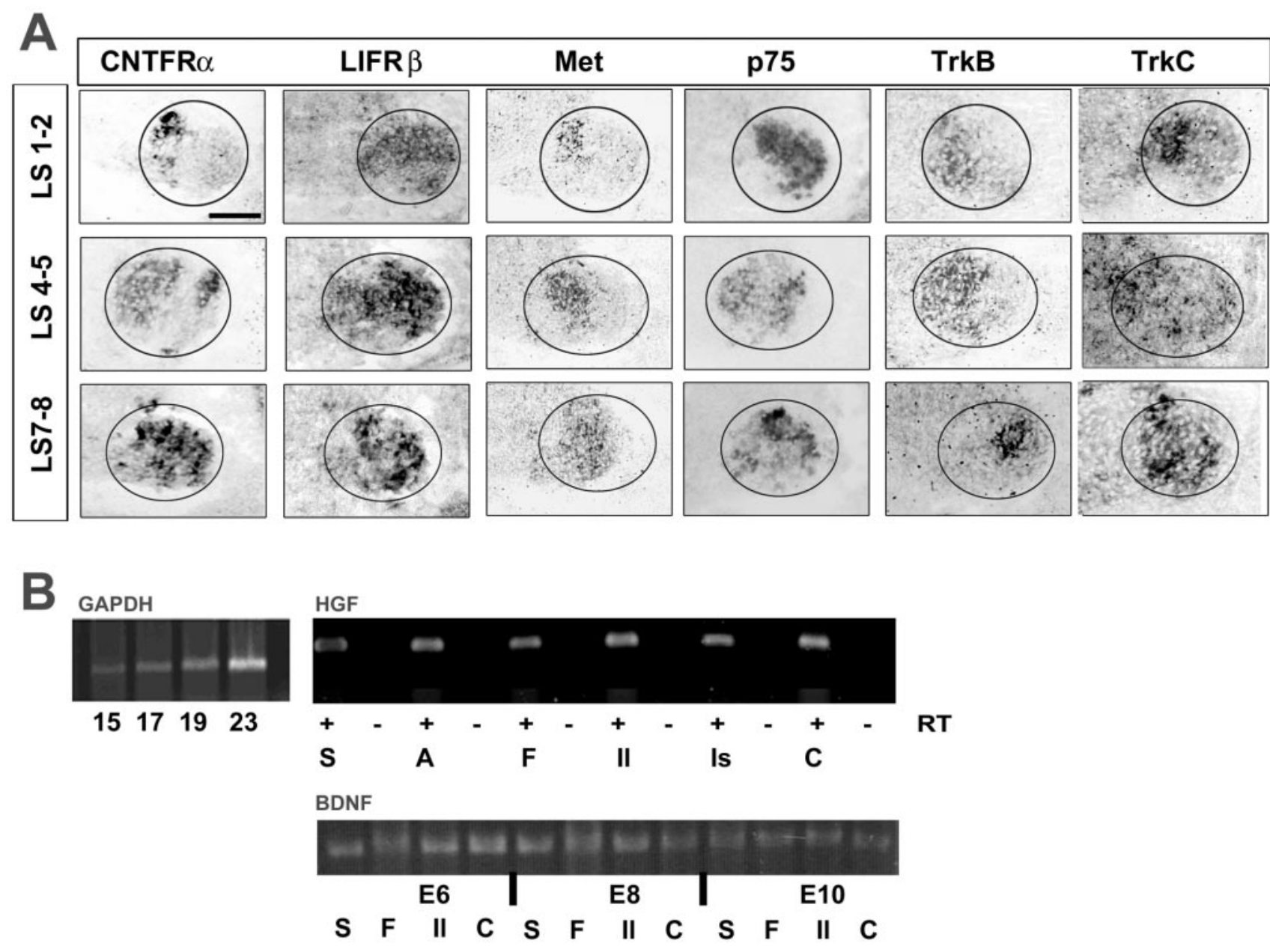

C
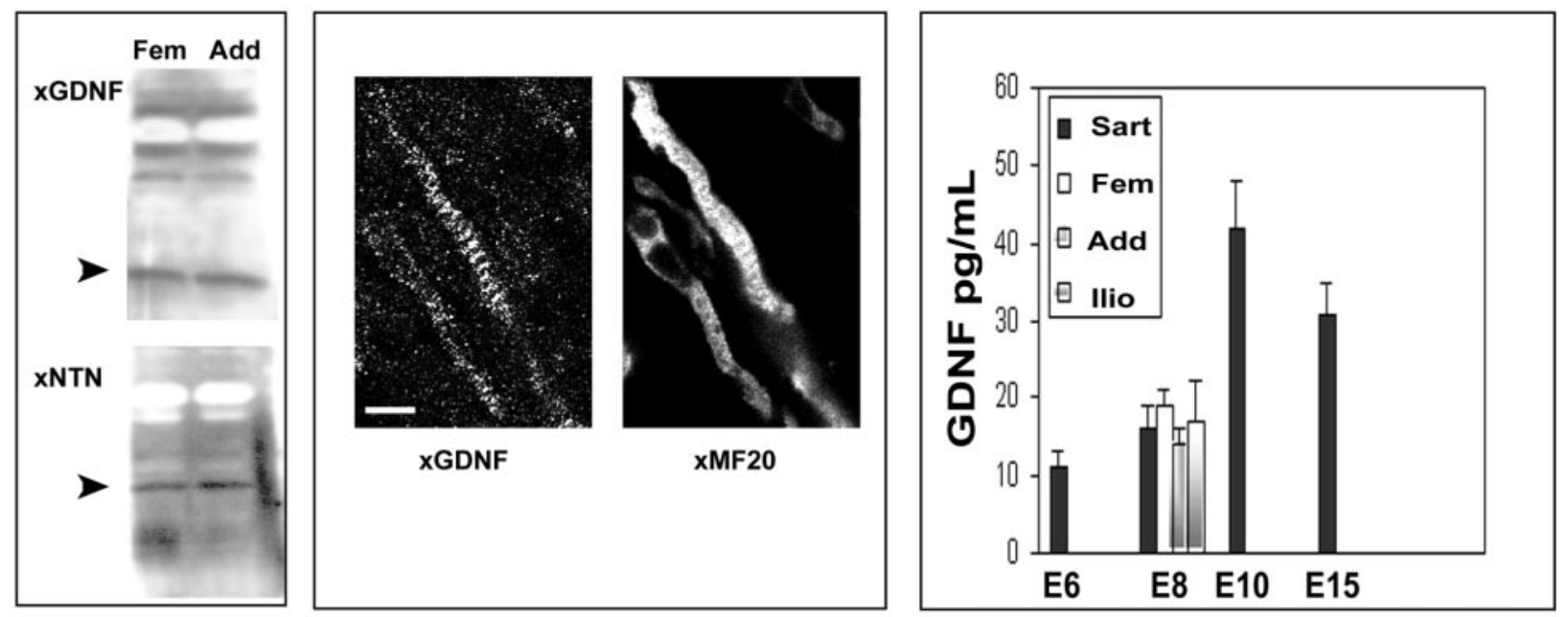

Figure 1. Heterogeneous expression of NTF-R mRNAs in the lumbar spinal cord versus homogeneous expression of NTFs in hindlimb muscles at E8, the peak of MN PCD. A, Transverse sections of three different rostrocaudal levels of the lumbar spinal cord reveal spatial differences in the expression of different NTF-RmRNAs. Ellipses encircle the LMC. Medial is to the left, and lateral to the right. Scale bar, $100 \mu \mathrm{m}$. B, RNA was extracted from individual muscles at E6, E8, or E10; reverse transcribed; and subjected to semiquantitative PCR with primers designed against chick BDNF, HGF, and GAPDH. The intensity of the GAPDH PCR product increases linearly between 15 and 23 cycles (left). Similar amounts of HGF PCR product are present in six hindlimb muscles at E8 (top right). Equal amounts of BDNF PCR product are present in four hindlimb muscles at E6, E8, and E10 (bottom right). S, Sartorius; A, adductor; $F$, femerotibialis; $;$, iliofibularis; Is, ischioflexorius; $C$, caudilioflexorius; RT, reverse transcriptase. C, Left, Immunoblot analysis reveals similar amounts of GDNF and NTN protein in the adductor and femerotibialis hindlimb muscles at E8. Molecular weight of GDNF and NTN are 19 and $25 \mathrm{kDa}$, respectively (arrowheads). Middle, Immunohistochemical detection of GDNF (left) in muscle cells identified by sarcomeric myosin (MF20) immunoreactivity (right). Scale bar, 5 $\mu \mathrm{m}$. Right, GDNF protein quantitation by ELISA demonstrates equivalent amounts of GDNF in various hindlimb muscles at E8, the peak of MN PCD. 
cells within a muscle, independent of their proximity to nerve branches and terminals labeled with neurofilament and synaptic vesicle antibodies (data not shown). Collectively, these data suggest that both extrafusal and intrafusal muscle fibers (or fibroblast- and Schwann cell-containing nerves within these targets) do not appear to selectively express different amounts of NTFs during the period of MN PCD.

\section{The adductor motor pool expresses a} distinct combination of NTF-Rs

Because different hindlimb muscles fail to selectively express NTFs, we next asked whether the spatial differences in NTF-R expression within the lumbar spinal cord could be related to pools of MNs innervating individual muscles. Retrogradely labeled adductor MNs were identified within the medial half of the lumbar LMC from segments LS1-3, and groups of four adjacent labeled sections were then examined for NTF-R mRNA. Four distinct patterns were identified: (1) restriction to only MNs within the adductor and not adjacent regions (CNTFR $\alpha$ and cMet) (see Fig. 3C); (2) expression by both adductor $\mathrm{MNs}$ and adjacent regions (cRet, TrkB, TrkC, p75, gp130, LIFR $\beta$ ) (see Fig. 3A-C); (3) exclusion from adductor MNs but expression by adjacent regions (GFR $\alpha 2$ and GFR $\alpha 4$ ) (see Fig. 3A); and (4) expression by a subpopulation of adductor $\mathrm{MNs}$ $(\mathrm{GFR} \alpha 1)$ (see Fig. $3 A, D$ ). In all but the fourth group, expression of NTF-Rs did not differentiate between individual adductor MNs. Thus, with the exception of GFR $\alpha 1$, NTF-R expression failed to identify subtypes of adductor MNs that are differentially equipped to compete for select NTFs.

The adductor is actually composed of two distinct extensors with different fiber type (the slow, medial, or superficial adductor and the fast, lateral, or deep adductor) (Dahm and Landmesser, 1991; Schroeter and Tosney, 1991). To directly test whether GFR $\alpha 1$ expression is limited to the medial adductor motor pool, we analyzed GFR $\alpha 1$ expression from LS1-3 in the spinal cord of embryos in which the medial adductor was removed, and only the lateral adductor was injected with retrograde tracer. Fig. $2 D$ shows that lateral adductor-innervating MNs fail to express GFR $\alpha 1$. These results further suggest that MNs projecting to an individual adductor muscle, and therefore competing for survival, are not different in their complement of NTF-Rs. However, because GFR $\alpha 1$ is present within the medial, but not lateral, adductor pool, groups of MNs

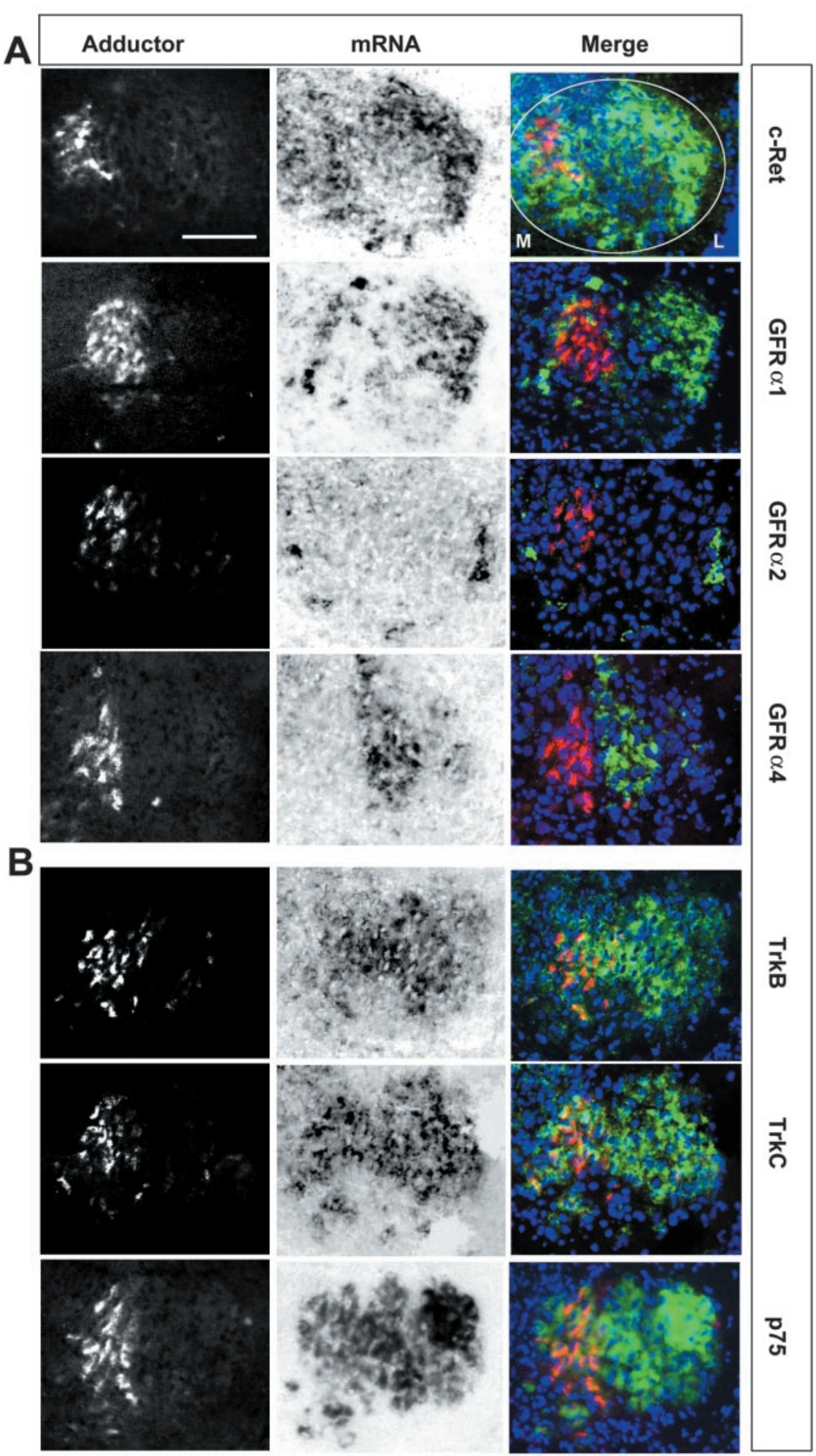

Figure 2. NTF-R expression by the adductor motor nucleus. The adductor muscles of the chick were injected with Alexa-Fluor 594-conjugated $\beta$-subunit cholera toxin, and retrogradely labeled MNs were identified and imaged on fresh-frozen spinal cord transverse sections (left). Sections were then processed for in situ hybridization analysis of specific NTF-Rs (middle). Images could be compared with the aid of Hoechst-labeled nuclei (blue in right column), which were captured before and after in situ hybridization. $A$, The adductor motor pool expresses the GDNF family receptor cRet and GFR $\alpha 1$ but not GFR $\alpha 2$ or GFR $\alpha 4$. B, All MNs within the adductor motor pool express the NTF-Rs TrkB, TrkC, and p75. C, All adductor MNs express the neuropoietic cytokine receptors LIFR $\beta$, gp130, and CNTFR $\alpha$ and the HGF receptor CMet. D, Lateral LMC MNs fail to express GFR $\alpha 1$. The medial adductor from an E8 embryo was surgically removed, and the lateral adductor was retrogradely labeled. The top row shows GFR $\alpha$ I mRNA expression in the medial portion of the LMC, where medial adductor MNs are usually detected. The bottom row shows that GFR $\alpha$ I expression fails to colocalize with the more laterally situated lateral adductor MNs. Large dots indicate the LMC, whereas small dots in the bottom row indicate lateral adductor MNs. Medial is to the left, and lateral to the right. Scale bar (in A), $50 \mu \mathrm{m}$. 

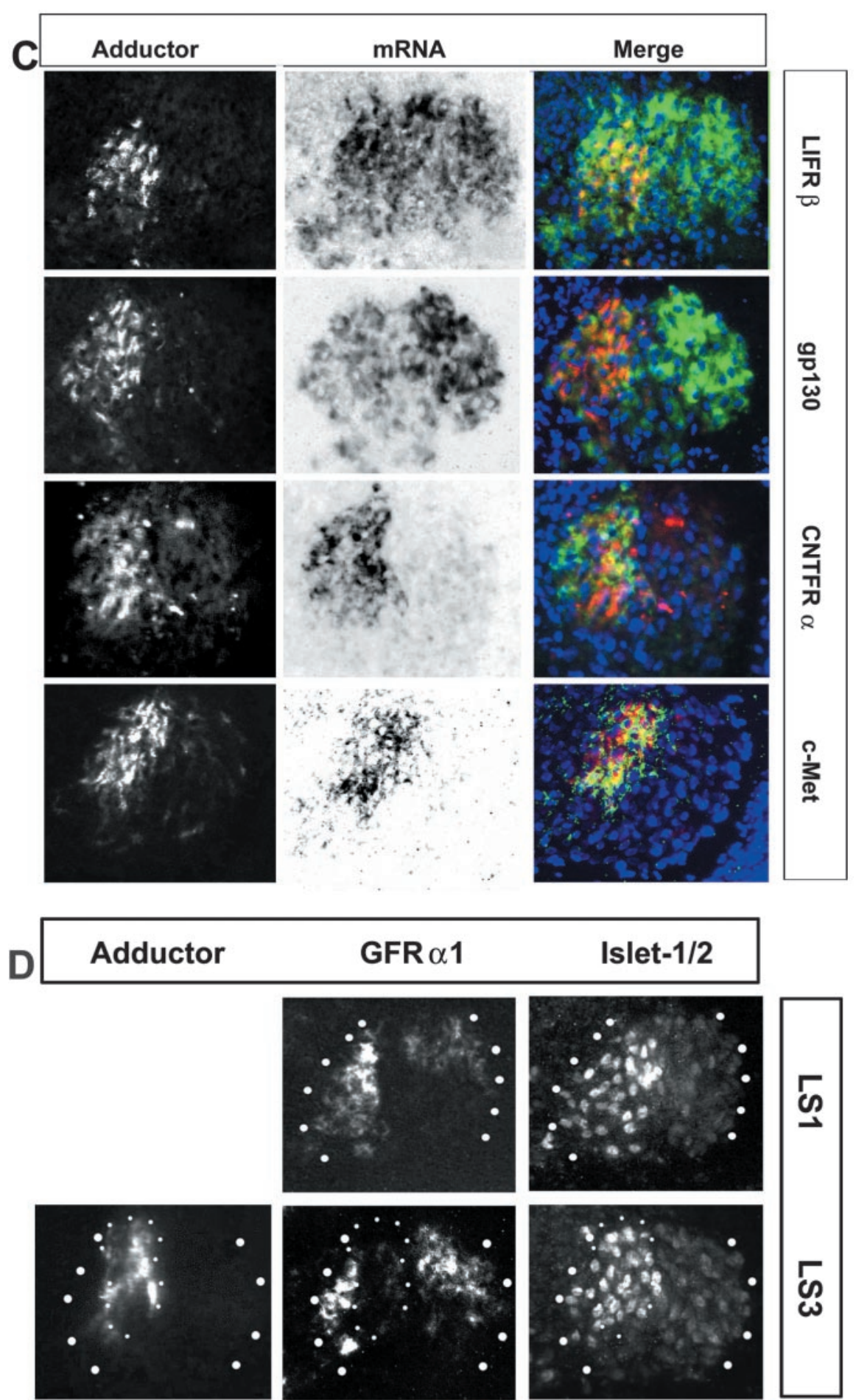

Figure 2. Continued

femerotibialis, and sartorius motor pools were retrogradely labeled with different tracers, CNTFR $\alpha$ immunoreactivity is restricted to the adductor pool and is expressed by virtually every islet1/2-positive adductor MN (Fig. 3). Because some MN NTF-Rs appear temporally regulated in their expression during the cell death period (McKay et al., 1996; Yamamoto et al., 1997; Novak et al., 2000), we analyzed adductor pool-specific patterns at E6, E8, and E10 and found them to be the same for all NTF-Rs (data not shown). However, after the cell death period, cMet mRNA was downregulated in adductor MNs, whereas other trophic receptors continued to be expressed by this motor pool until at least E15 (data not shown). Finally, we examined several other lumbar motor pools and failed to detect differences in NTF-R expression between MNs in these pools (Fig. 5; data not shown). Collectively, these results suggest that MNs within individual lumbar motor pools do not exhibit differential competence to survive the period of cell death attributable to NTF-R expression patterns.

\section{Stimulation of adductor MNs with multiple, but not individual, trophic factor ligands completely prevents their death}

Although different regions of the lumbar spinal cord express different combinations of NTF-Rs, virtually all MNs within a motor pool possess the same complement. In contrast, NTFs themselves appear to be expressed by all target muscles. To determine whether MN responses to excess NTF treatment in vivo are directly related to their NTF-R expression complement, we treated embryos in ovo from E6 to E9 with various NTFs and retrogradely labeled the adductor motor pool at E10. Treatment with BDNF, CNTF, GDNF, or HGF (but not NT-3) from E6 to E9 rescued a significant percentage of adductor MNs but failed to rescue them all, suggesting that NTF-R mRNA expression is insufficient to maintain the survival of all MNs, even in the presence of excess amounts of an individual NTF (Fig. 4B). The failure to rescue lumbar MNs in vivo with NT-3 is consis-

projecting to different adductor muscles express different combinations of NTF-Rs.

To more rigorously examine whether individual NTF-Rs are expressed by all MNs projecting to an adductor muscle, we analyzed the expression pattern at E8 of CNTFR $\alpha$ protein every 150 $\mu \mathrm{m}$ along the rostrocaudal extent of the adductor (medial and lateral) motor pool. Adjacent motor pools innervating the iliochanterici, sartorius, and femerotibialis muscles are also located in this same segmental region (Landmesser, 1978). In transverse spinal cord sections throughout LS1-3, in which the adductor, tent with previous studies (Kalcheim et al., 1992; Oppenheim et al., 1992).

Although the addition of single NTFs rescued only a percentage of adductor MNs from PCD, combined treatment with BDNF, GDNF, CNTF, and HGF together from E6 to E9 completely blocked adductor $\mathrm{MN}$ cell death (Fig. $4 B, C$ ). The addition of any three of these factors failed to completely rescue adductor MNs (data not shown). Treatment with all four factors and NGF also rescued all adductor MNs, indicating that in this situation 

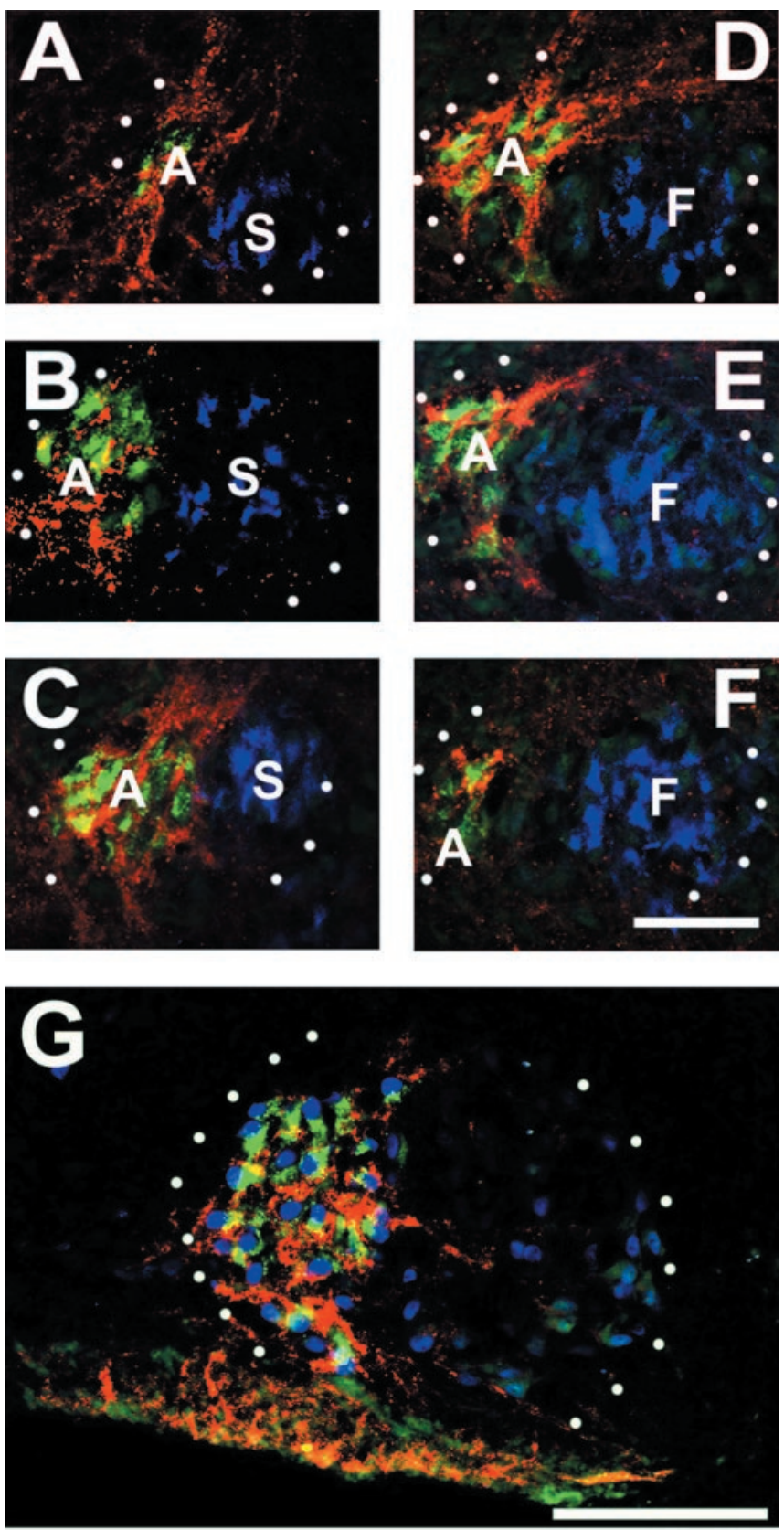

Figure 3. Virtually all MNs within the adductor motor pool express CNTFR $\alpha$. Adductor MNs were retrogradely labeled at $\mathrm{E} 8$ with HRP, and both sartorius and femerotibialis MNs were also retrogradely labeled at E8 with Alexa-Fluor 488-conjugated $\beta$-subunit cholera toxin (blue channel). Sections were immunolabeled with (y2- and (y5-conjugated antibodies against HRP (green) and CNTFR $\alpha$ (red). The images in $A-F$ are every 15 th $10 \mu \mathrm{m}$ section, proceeding from the rostralmost (LS1) to the caudalmost (LS3) portion of the adductor pool. All adductor MNs (green), but neither sartorius nor femerotibialis MNs (blue), express CNTFR $\alpha$ protein (red). A, Adductor; S, sartorius; F, femerotibialis. G, Islet1/2-positive MNs (blue) in LS2 in the adductor motor pool (green) are immunoreactive for CNTFR $\alpha$ (red). The white dots in indicate the LMC. Scale bars: $A-F, 50 \mu \mathrm{m} ; G, 75 \mu \mathrm{m}$.

NGF could not activate death signaling in MNs through p75 (Hughes et al., 1993; von Bartheld et al., 1994). Rescue of all adductor MNs was maintained until E15, the last day examined, but required continued treatment with these excess factors during the period from E6 to E15 (data not shown). Finally, treatment with all four factors rescued $60 \%$ of all of the MNs normally destined to undergo cell death within the entire lumbar spinal cord $[18,370$ (treated) vs 11,540 (control); $n=4]$. These results suggest that within populations of MNs, the receptor expression profile of which is well characterized, stimulation of multiple NTFs but not individual NTFs is sufficient to completely rescue all MNs from cell death.

Although NTF-R mRNA and protein are expressed by all adductor MNs, we noticed striking differences in the subcellular pattern of NTF-R immunoreactivity in lumbar MNs, using antibodies to cRet, TrkB, TrkC, and CNTFR $\alpha$ (chick-specific GFR $\alpha 1$ and cMet antibodies for immunohistochemistry are currently unavailable). Whereas cRet immunoreactivity was detectable only in proximal somata and ventral root, TrkB immunoreactivity was observed most strongly in dendrites (process extending throughout the ventral horn and especially into the white matter) and more weakly in the ventral root. CNTFR $\alpha$ immunoreactivity was present in axons in the ventral root, whereas TrkC immunoreactivity was detected only in cellular processes immediately outside of and almost encircling the entire LMC (Fig. 4D). These different subcellular patterns may contribute to the ability of different NTFs to collectively stimulate greater amounts of adductor MN survival (Janiga et al., 2000).

\section{Nerve-derived NTF-Rs regulate MN survival through signaling in trans}

Whereas the above results demonstrate that individual and combined NTF treatment is sufficient to rescue some or all adductor MNs, respectively, other observations led us to question whether stimulation of specific adductor MN-derived NTF-Rs was necessary for adductor MN survival. We pursued this question in two ways: first, by testing the degree to which stimulation of NTF-Rs that are not expressed by adductor MNs themselves could nonetheless contribute to their survival, and second, by directly interfering with adductor MN-derived NTF-R expression.

We noticed that although nearly every adductor neuron expresses cRet, only rostral medial adductor MNs express GFR $\alpha 1$. The in ovo addition of GDNF from E6 to E9 rescued slightly more than half of the total number of adductor MNs, and these appeared equally distributed between putative medial and lateral adductor motor pools (data not shown), suggesting that excess GDNF may have activated cRet in these GFR $\alpha 1$-negative lateral adductor MNs by some other mechanism. We envisioned two possibilities: GDNF indirectly rescues lateral adductor MNs by activating GFR $\alpha 1$ and c-Ret signaling in other cells, which then produce other molecules that rescue adductor MNs; or GDNF, which can activate GFR $\alpha 2$ at a high concentration (Klein et al., 1997), activates cRet in trans in lateral adductor MNs through the expression of GFR $\alpha 1$ or GFR $\alpha 2$ of an adjacent cell (Paratcha et al., 2001; Ledda et al., 2002).

To distinguish between these possibilities, we first analyzed the expression of various GFR $\alpha$ receptors in adjacent cell types. GFR $\alpha 2$ and GFR $\alpha 4$ mRNA, but not GFR $\alpha 1$ or cRet mRNA, was detected in the lumbar ventral roots and peripheral nerves of E8 chick embryos (Fig. 5B; Table 1). Because receptors for NTN and PSP are expressed by cells in motor nerves but not by adductor MNs themselves, we then added NTN or PSP to embryos from E6 to E9 and retrogradely labeled these MNs on E10. Similar to the effects of GDNF in rescuing GFR $\alpha 1$-deficient lateral adductor MNs, both NTN and PSP rescued GFR $\alpha 2$ - and GFR $\alpha 4$-deficient adductor MNs from cell death (Fig. 5A). To exclude the possibility that exogenous GDNF, NTN, or PSP exerted their MN rescue effects indirectly through other cells coexpressing cRet and GFR $\alpha$, we tested whether these factors could rescue MNs that fail to express cRet (Poteryaev et al., 1999; Trupp et al., 1999). We examined the responsivity of MNs innervating the medial gas- 
A

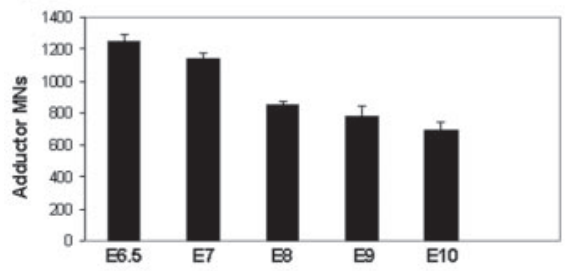

B

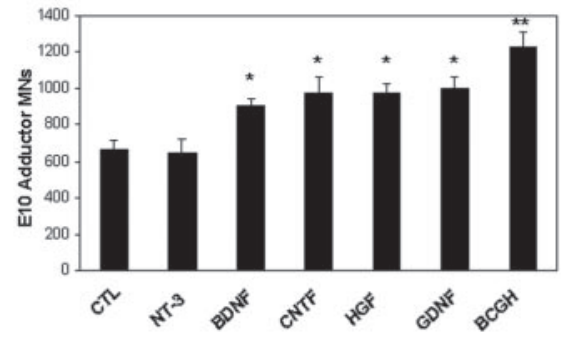

C
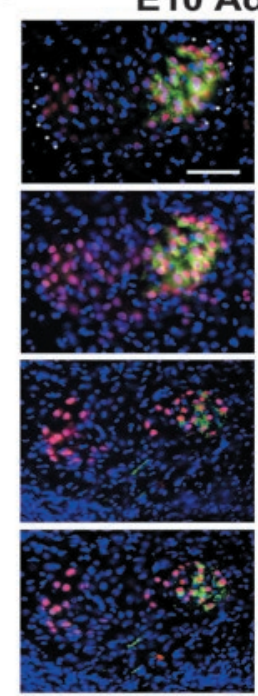

D

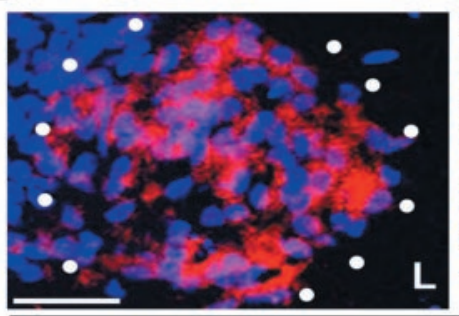

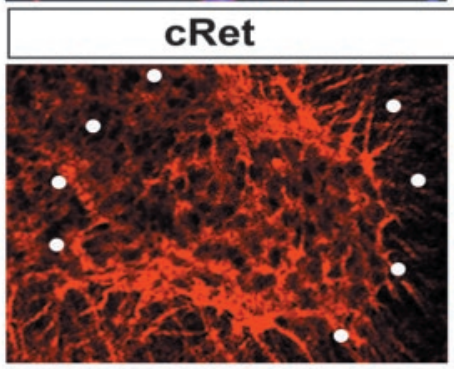

TrkB

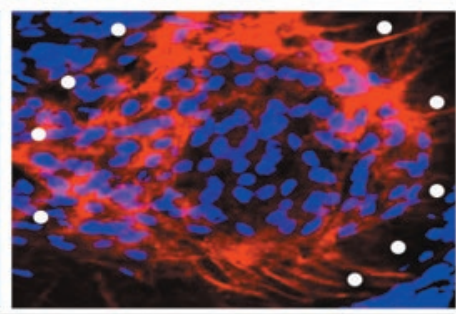

CNTFR $\alpha$

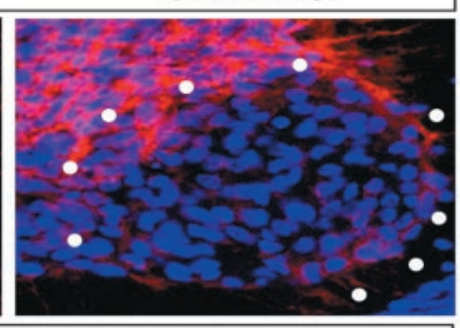

TrkC

Figure 4. In ovo treatment with multiple, but not individual, NTFs rescues all adductor MNs from PCD. A, Adductor muscles were injected with HRP at different times during the period of MN PCD (E6-E10). MNs innervating the adductor are reduced by about one-half during the normal period of PCD. $B$, Treatment with individual NTFs ( $5 \mu \mathrm{g}$ daily from E6 to E9) partially rescues adductor MNs from $P C D$, whereas combined treatment with BDNF, GDNF, CNTF, and $\mathrm{HGF}(\mathrm{B} / \mathrm{G} / \mathrm{C} / \mathrm{H})$ completely prevents adductor MN PCD (compare BCGH with E6.5 in A). Data represent the mean \pm SD; $n=5$ for all conditions. ${ }^{*} p<0.05$ versus control; ${ }^{* *} p<$ 0.01 versus control and versus single-factor, Student's t test with Bonferroni corrections. $C$, Representative images of cross sections at E10 of the adductor motor pool in embryos treated from E6 to E9 with multiple NTFs (top four images) and in control embryos (bottom four images). The right column contains the same images as the left column at higher magnification. Retrogradely labeled MNs were quantified by counting the number of HRP (green) and islet1/2 (red)-immunoreactive nuclei (blue). The white dots in the left column denote the medial and lateral borders of the LMC. The white arrows in the right column depict the individual countable adductor MNs in these two conditions, the totals of which are presented in the bottom right corner for each condition. The top and bottom rows of each treatment condition are the same images at different focal planes to illustrate all of the adductor MNs within the $10 \mu \mathrm{m}$ section. D, Differences in subcellular patterns of immunoreactivity for specific NTF-Rs (red) at E8, counterstained with Hoechst (blue). The LMC is enclosed with dots. Medial is to the left, and lateral (L) to the right. Hoechst counterstain is omitted for TrkB to better visualize immunoreactivity. Scale bar: $C, D, 50 \mu \mathrm{m}$.

trocnemius (MG) to daily (E6-E9) treatment with exogenous GDNF. These MNs, which express GFR $\alpha 1$ but not cRet, fail to be rescued from cell death by excess GDNF, NTN, or PSP, suggesting that cRet expression by MNs is necessary for them to respond to excess GDNF family ligands (Fig. 5C,D). In contrast, MG MNs express CNTFR $\alpha$ and in ovo treatment with CNTF promotes their survival, indicating that these $\mathrm{MNs}$ are not inherently unresponsive to NTFs (Fig. 5C,D). In summary, these results provide the first evidence that NTFs can rescue $\mathrm{MNs}$ in vivo through signaling in trans from nerve-derived GFR $\alpha$ expressing cells to cRet-expressing MNs.

\section{Target-derived NTF-Rs expression fails to mediate $\mathrm{MN}$ survival signaling in trans}

Because NTF-Rs are expressed in other cell types known to interact with MNs (Table 1 ), we sought to characterize their capacity to either signal indirectly or in trans to MNs. A number of NTF-Rs are expressed by non-muscle cells within the limb (Table 1 ), including CNTFR $\alpha$, the protein of which is expressed in a distinctive latticelike pattern in all hindlimb muscles (Fig. $6 \mathrm{~A}$ ). This pattern is similar to that observed for fibronectin expression (Fig. $6 B$ ) and other proteins associated with the muscle extracellular matrix. To determine whether CNTFR $\alpha$ protein was expressed by cells within the muscle or exported there by $\mathrm{MN}$ axons, we examined muscles such as the sartorius, the MNs of which do not express CNTFR $\alpha$. The same staining pattern could be detected in sections of this muscle (data not shown), indicating that CNTFR $\alpha$ immunoreactivity in the limb likely originates from cells within the muscle. We confirmed this by demonstrating CNTFR $\alpha$ mRNA in cells within the connective tissue between muscles as well as in small non-muscle cells within the muscle (Fig. 6C). Combined with our inability to detect CNTFR $\alpha$ in conditioned medium extracted from E5 MN primary cultures (data not shown), these data support the idea that fibroblasts or other non-muscle cell types within the muscle express CNTFR $\alpha$ protein in the extracellular matrix.

Because we have shown that nervederived (presumably Schwann cellderived) GFR $\alpha 2$ and GFR $\alpha 4$ are able to signal in trans to cRet-expressing MNs, we next asked whether CNTFR $\alpha$ expressed by fibroblasts in the muscle could act similarly to rescue MNs expressing LIFR $\beta$ and gp130 but not CNTFR $\alpha$. Whereas both the adductor and sartorius muscles express CNTFR $\alpha$, only MNs innervating the adductor are also CNTFR $\alpha$ positive. We added CNTF in ovo from E6 to E9 and retrogradely labeled both these motor pools. CNTF rescued adductor but not sartorius MNs, indicating that CNTFR $\alpha$ stimulation in the target is not sufficient to rescue CNTFR $\alpha$-negative MNs projecting to that target (Fig. $6 D$ ). To rule out the possibility that sartorius MNs are inherently incapable of responding to CNTF because of mechanisms other than the failure to express CNTFR $\alpha$ (e.g., inhibitory intracellular signaling), we ectopically expressed 
CNTFR $\alpha$ in the sartorius motor pool, exclusively during the period of MN PCD (Sato et al., 2002), by in ovo electroporation $(6 E, F)$. Treatment with CNTF from E6 to E9 rescued sartorius MNs in $\mathrm{CNTFR} \alpha$-overexpressing embryos (584 vs $415 ; n=3$; $p<$ 0.05 , Student's $t$ test). Finally, to determine whether exogenous CNTFR $\alpha$ can mediate MN survival, we added CNTF and soluble CNTFR $\alpha$ from E6 to E9 and counted retrogradely labeled sartorius MNs. Cotreatment with CNTF and soluble CNTFR $\alpha$ rescued a significant percentage of sartorius MNs from cell death (Fig. 6D). These results indicate that whereas intracellularor extracellular-derived CNTFR $\alpha$ can activate gp130/LIFR $\beta$ in MNs in response to exogenous CNTF, CNTFR $\alpha$ expressed by fibroblasts does not initiate such signaling in trans to the axons of CNTFR $\alpha$-negative MNs. Together, these results indicate that glycosylphosphatidyl inositol (GPI)linked receptors in the nerve, but not in muscle, targets activate tyrosine kinases expressed by MNs in response to NTF signals.

\section{Perturbation of GDNF or CNTF}

signaling fails to increase adductor $\mathrm{MN}$ cell death

Because MNs are rescued by some NTFs, the receptors of which are not expressed by MNs themselves, we then asked whether MN-derived NTF-R expression was necessary at all for MN survival. Accordingly, we blocked specific NTF signaling during the period of $\mathrm{MN}$ death and examined the effects of this treatment on MN survival. We used a mutant CNTF protein (AADHCNTF) that binds CNTFR $\alpha$ but lacks the amino acids necessary for the activation of LIFR $\beta$ and thus specifically antagonizes endogenous CNTF signaling through CNTFR $\alpha$ (Di Marco et al., 1996). Because the amino acids mediating this interaction are conserved between mouse and chicken (Heller et al., 1995; Duong et al., 2002), we first tested the ability of this antagonist to block survival induced by either CNTF or muscle extract (MEX) on primary $\mathrm{MN}$ cultures derived from E5 embryos. AADH-CNTF blocked MN survival induced by CNTF but not survival induced by MEX, confirming the effectiveness of AADH-CNTF and suggesting that molecules within MEX, other than CNTF, mediate MN survival in vitro (data not shown). We next added $100 \mu \mathrm{g}$ of AADH-CNTF daily in ovo from E6 to E9 based on previous reports that this antagonist is effective in vivo (MacLennan et al., 2000; Xu et al., 2001). The number of retrogradely labeled adductor MNs on E10 after such treatment was similar to control (Fig. 7A). To ensure the ability of exogenously applied antagonist to block CNTF signaling, we added CNTF alone (E6-E9), AADH-CNTF alone, or the two together and found that the increase in survival mediated by CNTF on adductor MNs was completely blocked by coadmin-

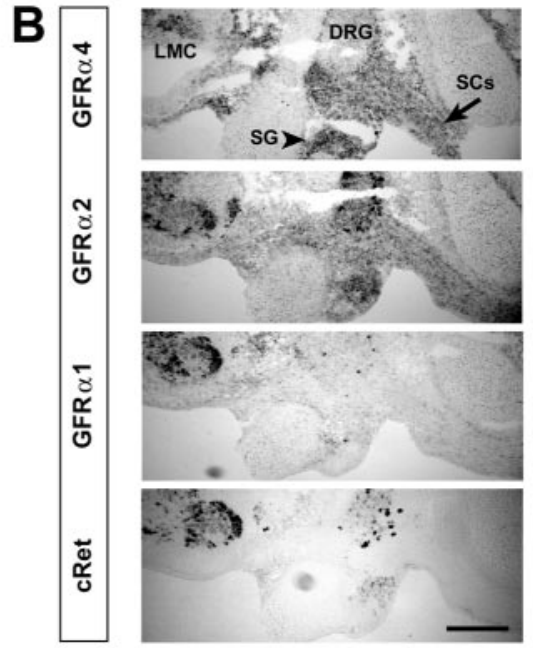

CTL GDNF PSP NTN CNTF

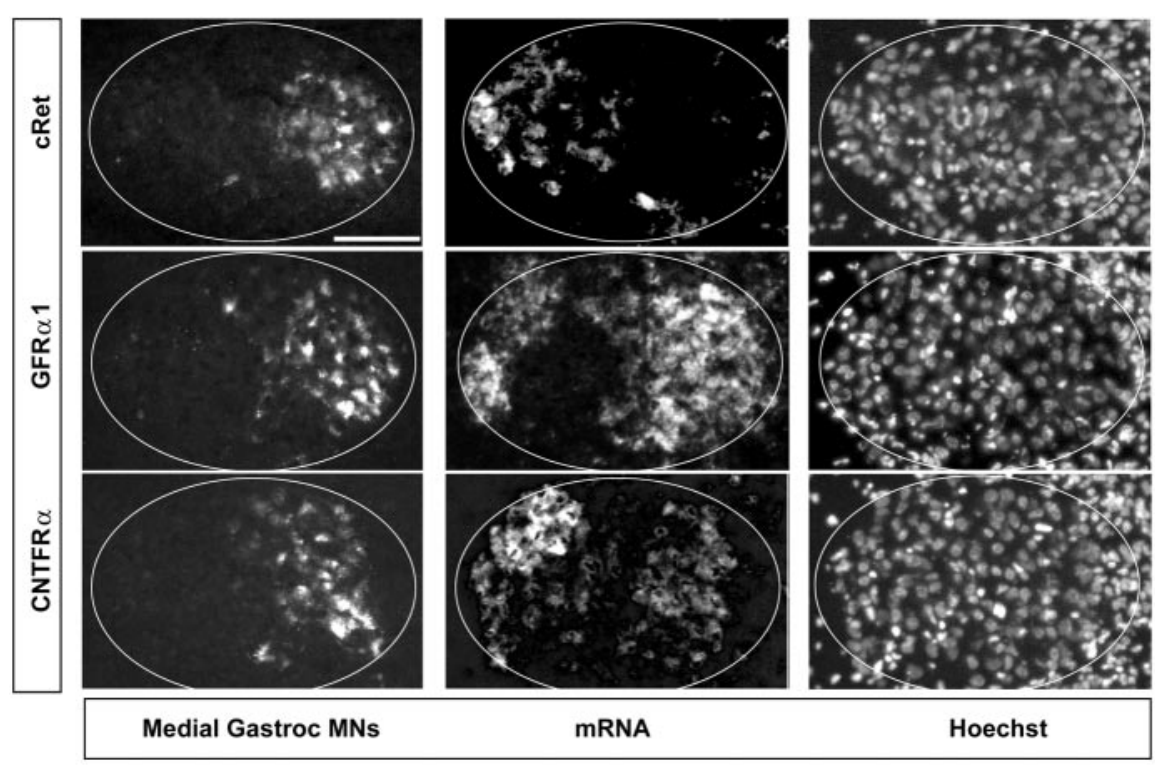

Figure 5. NTF-R expression by cells in the peripheral nerve mediates survival signaling in trans to MNs in vivo. A, In ovo treatment with $5 \mu \mathrm{g}$ of NTN or PSP from E6 to E9 rescues adductor MNs, which fail to express either GFR $\alpha 2$ and GFR $\alpha 4$, from PCD. $B, \mathrm{GFR} \alpha 2$ and GFR $\alpha 4$, but not GFR $\alpha 1$ or cRet, are expressed by putative Schwann cells (SCs) in the peripheral nerve. DRG, Dorsal root ganglion; SG, sympathetic ganglion. Scale bar, $250 \mu \mathrm{m}$. C, D, MN-derived expression of cRet is required for the rescue effects of GDNF family ligands. C, In ovo treatment with $5 \mu \mathrm{g}$ of CNTF but not GDNF, PSP, or NTN from E6 to E9 rescues MNs innervating the medial gastrocnemius (MG). D, MG-innervating MNs retrogradely labeled at E8 with Alexa-Fluor 594-conjugated $\beta$-subunit cholera toxin (left) express CNTFR $\alpha$ and GFR $\alpha 1$ mRNA (middle) but not cRet mRNA. Hoechst-stained nuclei are in the right panel. Scale bar, $50 \mu \mathrm{m}$. Data represent the means $\pm S D ; n=3$ for all conditions. ${ }^{*} p<0.05$ versus control; Student's $t$ test.

istration of AADH-CNTF. Whereas we and others have been unable to demonstrate the presence of chicken CNTF (GPA) in the muscle or nerve during the period of MN cell death (Sendtner et al., 1994), the expression of a relatively novel CNTFR $\alpha$ stimulating heterodimeric complex, cardiotrophin-like cytokine-1 (CLC)/soluble receptor cytokine-like factor-1 (CLF) (Senaldi et al., 1999; Elson et al., 2000), has been recently demonstrated to regulate MN survival (Alexander et al., 1999: Forger et al., 2003). Activation of LIFR $\beta$ and gp130 by CLC/CLFmediated binding is inhibited by CNTF (Elson et al., 2000), suggesting that, in our study, AADH-CNTF administration in ovo also blocked these CNTF-related cytokines from activating CNTFR $\alpha, \operatorname{LIFR} \beta$, and gp130 complexes. 
Table 1. The expression of NTF-Rs is heterogeneous within the neuromuscular system during the process of PCD

\begin{tabular}{lllllllll}
\hline Cell type (E6-E10) & cRet & GFR $\alpha 1$ & GFR $\alpha 2$ & GFR $\alpha 4$ & cMet & TrkB & TrkC & CNTFR $\alpha$ \\
\hline Schwann cells & - & - & $+^{a}$ & + & - & & - & - \\
Fibroblasts & + & + & - & - & - & - & - \\
Myoblasts & - & - & - & - & + & - & - & - \\
\hline
\end{tabular}

GFR $\alpha 2$ and GFR $\alpha 4$ transcripts are found in RNA extracts of the peripheral nerve, but it is not certain whether the expression of these molecules is by Schwann cells or by fibroblasts.

${ }^{a}$ Also in fibroblasts within nerve (1E8 negative).

We also tested the requirement for endogenous GDNF signaling to maintain the survival of adductor MNs during the period of cell death. Neutralizing antibodies against human GDNF successfully inhibit avian ciliary neuron target innervation (Hashino et al., 2001) as well as lumbar spinal cord expression of largeconductance calcium-activated potassium channels (MartinCaraballo and Dryer, 2002), when administered in ovo or into hindlimb muscles. Therefore, we delivered similar concentrations of this antibody $(15 \mu \mathrm{g})$ in ovo at E6 and E8 and quantified adductor MNs at E10. Whereas treatment with anti-GDNF, together with GDNF, attenuated the potent increase in adductor MN survival obtained with GDNF alone, treatment with the antibody alone failed to affect the number of MNs innervating the adductor, compared with control IgG-treated embryos (Fig. 7A). Because mice deficient in the GDNF gene exhibit a profound decrease in MN number during the period of PCD (Oppenheim et al., 2000), the failure of anti-GDNF treatment to affect adductor $\mathrm{MN}$ number was unexpected. To ensure that the antibody gained access to MNs, we directly injected a high dose $(5 \mu \mathrm{g} / \mu \mathrm{l})$ of anti-GDNF together with a retrograde tracer (Alexa-Fluor 594-conjugated cholera toxin $\beta$-subunit) at E7 directly into the hindlimb and counted dying lumbar MNs at E8. Figure 7, $B$ and $D$, shows that anti-GDNF injection markedly increases the number of dying lumbar MNs (islet1/2 staining not shown), relative to control IgG thigh-injected embryos. Although these results at first appeared at odds with those generated from in ovo antiGDNF treatment, further analysis revealed that the increase in dying MNs observed after anti-GDNF injection was strikingly restricted to the caudal lumbar spinal cord, which contains MNs that innervate non-adductor MNs (Fig. 7E). Because retrograde tracing revealed that the adductor motor pool indeed gained access to the limb-injected anti-GDNF (Fig. 7C), these results are consistent with those obtained from systemic anti-GDNF treatment and suggest that the survival of caudally located $\mathrm{MN}$ pools in the lumbar spinal cord is more susceptible than the adductor motor pool to the loss of GDNF signaling.

\section{Discussion}

Our results indicate for the first time that individual MNs projecting to the same target and hence competing for survival fail to differ significantly in their expression of many of the most well characterized NTF-Rs. These data also demonstrate that treatment with excess individual NTFs is incapable of rescuing all NTF-R-positive MNs within such a competition unit. However, administration of excess multiple NTFs rescues all competing MNs, suggesting that concerted NTF stimulation is sufficient to override potential death-promoting pathways. Additionally, we provide the first evidence that NTFs can rescue MNs by acting through NTF-Rs on adjacent cell types in vivo. Finally, we demonstrate that expression of some NTF-Rs is not necessary for adductor MN survival, suggesting that in the absence of these pathways there can be compensation by the activation of other pathways, or alternatively (but less likely) that these pathways are not involved in mediating MN PCD. Together, these studies pro- vide evidence for an unexpected complexity in the regulation of MN survival by NTFs.

\section{NTF-Rs are expressed heterogeneously in the spinal cord and homogeneously in motor pools}

One important finding of the present study is the homogeneity of expression of individual NTF-Rs within a motor pool. Virtually all adductor MNs either express particular NTF-Rs by E6 (the onset of MN cell death) or fail to express them. Whether the chief purpose of these expression patterns is to mediate survival competence or other aspects of development is unclear. In particular, cMet and CNTFR $\alpha$ are restricted to this pool at LS1-3, raising the possibility that these molecules are part of a genetic program related to adductor target identity. However, similar to the expression of ETS transcription factors and type II cadherins (Lin et al., 1998; Price et al., 2002), both of these receptors are also expressed by other pools in more caudal segments of the lumbar cord, indicating that their putative role in $\mathrm{MN}$ specification is not unique to the adductor pool. Additional ongoing studies are underway to analyze the developmental function of these patterns before the period of cell death (Ebens et al., 1996).

\section{NTFs are expressed in all hindlimb muscles during MN PCD}

Every NTF examined was present within all limb muscles examined between E6 and E10. Similarly, BDNF protein levels, measured by a highly sensitive electrochemiluminescent immunosorbent assay, fail to differ between chick thigh muscles during the period of MN PCD (Vernon et al., 2004). These results, together with the fact that every neuron within a pool expresses specific NTF-Rs, suggest that differential target expression of these molecules does not likely account for the normal reduction of MNs by PCD. This is consistent with a recent finding that motor axons remain largely unaffected by ectopic sources of NTFs in the periphery (Tucker et al., 2001). Because we only examined NTF distribution and levels in individual muscles during the period of cell death (E6-E10), and after motor axons arrive at their targets (Tosney and Landmesser, 1985), we cannot exclude a more spatially restricted expression pattern of specific NTFs at earlier times that may impart a subtype-specific MN fate (Haase et al., 2002). Although we made no attempt to discriminate extrafusal from intrafusal muscle fibers, the relatively homogeneous expression of GDNF within muscles suggests that this NTF is expressed by both these fiber types.

\section{Stimulation with multiple, but not individual, NTFs completely rescues adductor motor neurons from PCD}

Although NTF treatment has previously been observed to be incapable of rescuing some populations of NTF-R-positive MNs from death (Steljes et al., 1999; Caton et al., 2000; Novak et al., 2000), this effect extended to an entire subpopulation of competing MNs. In contrast, we showed that such subpopulations themselves are heterogeneous in responding to specific NTFs. Therefore, it appears that additional factors other than NTF-R 
expression itself regulate trophic responses to NTFs. The identity of these factors may include extracellular inhibitors of specific NTFs/NTF-Rs, such as noggin, which antagonizes BMPRs (Zimmerman et al., 1996), intracellular regulators of NTF-R phosphorylation, such as SHP phosphatases (Tran et al., 2003), or proteins that modulate any of the numerous downstream effectors, such as TRB3, a newly discovered negative regulator of Akt (Du et al., 2003).

One potential cellular mechanism for the differential effects of individual versus combined NTF treatment on adductor MN survival may involve the strikingly different subcellular expression patterns of NTF-Rs. For example, the increased subcellular pattern of TrkB protein in dendrites and its reduced expression in ventral root axons suggest that the source of BDNF for MNs during the period of cell death, like those during MN differentiation (Jungbluth et al., 1997), may originate from afferent input and not from target muscle (Okado and Oppenheim, 1984; Furber et al., 1987; Yan et al., 1993; von Bartheld et al., 1996). Because differential sources of NTF signaling may exert specific survival and growth effects on MNs (Arce et al., 1998; Janiga et al., 2000; Peng et al., 2003), it seems possible that the complete rescue of adductor MNs by excess stimulation of various NTF-Rs may mimic or amplify multiple developmentally relevant signals.

\section{Nerve-derived, but not target-derived, GPI-linked NTF-Rs mediate MN survival in trans}

We demonstrated that GPI-anchored receptors are able to mediate trophic signals to MNs in trans (Trupp et al., 1997; Yu et al., 1998; Paratcha et al., 2001) if they are expressed by cells in the nerve (GFR $\alpha 2$, GFR $\alpha 4$ ) but not when expressed by cells in the target (CNTFR $\alpha$ ). Because GFR $\alpha 2$ but not GFR $\alpha 1$ is expressed by Schwann cells, the survival effect on lateral adductor MNs mediated by GDNF signaling in trans is likely attributed to this receptor because GDNF is capable of binding to GFR $\alpha 2$ with low affinity (Klein et al., 1997). Alternatively, GFR $\alpha 1$ expressed by non-muscle cells in the limb could mediate this effect (Table 1). However, this seems less likely because of (1) the dispensability of limbderived GRF $\alpha 1$ expression for achieving appropriate Ret signaling to spinal MNs in vivo ( $\mathrm{H}$. Enomoto, personal communication), and (2) the inability of targetderived CNTFR $\alpha$ to signal to CNTFR $\alpha$ negative sartorius MNs. Finally, because
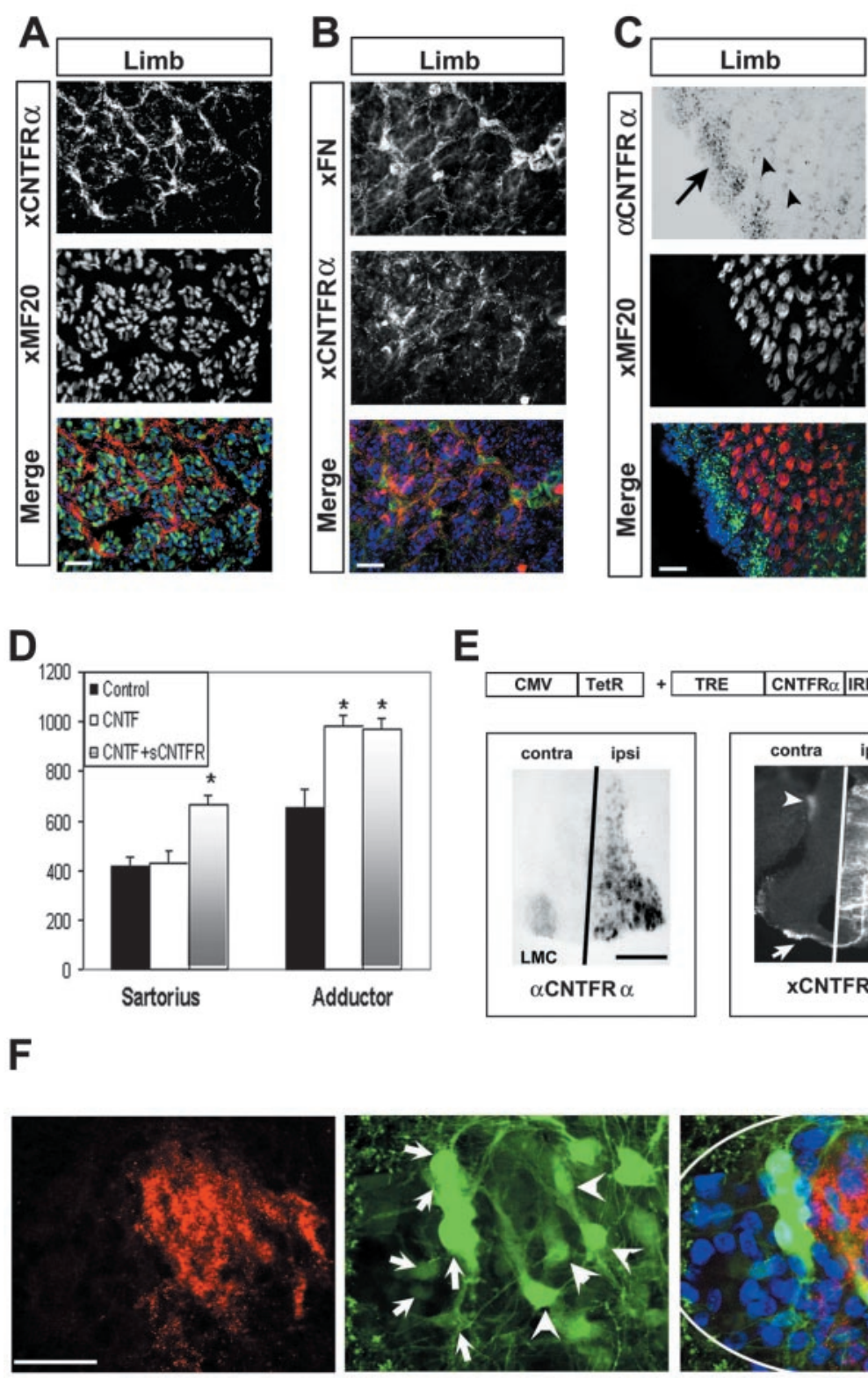

E

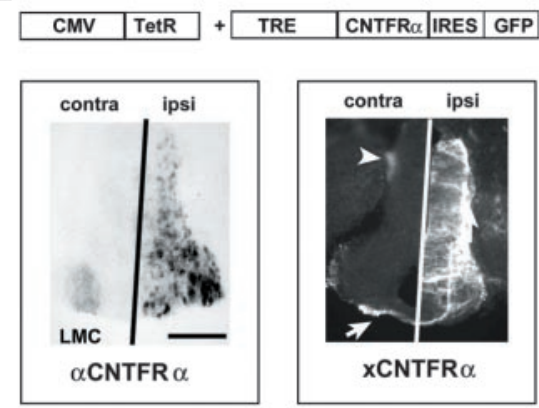

\section{$F$}

Figure 6. NTF-R expression by non-muscle cells in the limb does not mediate survival signaling in trans to MNs in vivo. $A$, CNTFR $\alpha$ immunoreactivity (top; red in bottom panel) is detected in transverse sections of the chick hindlimb at E8 but does not colocalize with sarcomeric myosin (MF20) immunoreactivity (middle; green in bottom panel). $B$, CNTFR $\alpha$ immunoreactivity (top; red in bottom panel) colocalizes with fibronectin immunoreactivity (middle; green in bottom panel) in the chick hindlimb at E8.C, CNTFR $\alpha$ mRNA (top; green in bottom panel) is expressed by non-muscle cells in the chick hindlimb at E8, both within the muscle (arrowheads) and in the connective tissue surrounding the muscle (arrow), but does not colocalize with sarcomeric myosin (MF20) immunoreactivity (middle; red in bottom panel). Hoechst-stained nuclei are blue in the bottom panel in $A-C$. Scale bars: $A-C$, $50 \mu \mathrm{m}$. D, In ovo treatment with $5 \mu \mathrm{g}$ of CNTF from E6 to E9 rescues adductor but not sartorius MNs from PCD. In contrast, treatment with CNTF and soluble CNTFR $\alpha$ rescues sartorius MNs. Data represent the means $\pm S D ; n=4$ for all conditions. ${ }^{*} p<$ 0.05 versus control; Student's t test. $E$, Diagram of constructs used to overexpress chicken CNTFR $\alpha$ in MNs during the period of PCD. Two plasmids, one containing the tetracycline repressor protein (TetR) cDNA driven by the cytomegalovirus (CMV) promoter, the other containing chicken CNTFR $\alpha$ and GFP cDNAs expressed as a single bicistronic transcript under the control of the tetracycline repressor response element (TRE), were electroporated at E3 into the chicken neural tube. Doxycycline (100 mg) was added at E3 and E4 to initiate gene expression, and the embryo was killed at E4.5 and examined for CNTFR $\alpha$ mRNA (left) or protein (right). Note the expansion of CNTFR $\alpha$ mRNA and protein to the electroporated half of the spinal cord (ipsi), compared with the restriction of CNTFR $\alpha$ mRNA to MNs (LMC) and CNTFR $\alpha$ protein to the dorsal roots (arrowhead) in the control half (contra). The arrowhead in the right panel indicates ectopic CNTFR $\alpha$ immunoreactivity exhibited by crossing commissural interneuronal fibers. Scale bar, $200 \mu \mathrm{m}$. F, Expression of CNTFR $\alpha$ at E10 in the rostral lumbar spinal cord after electroporation of chicken CNTFR $\alpha$ constructs at E3 and doxycycline treatment from E6 to E9. Ectopic CNTFR $\alpha$-positive MNs, detected by examining GFP expression (green in the middle and right panels), are observed lateral to their usual adductor motor pool domain (red in the left and right panels). The arrowheads indicate CNTFR $\alpha$-overexpressing MNs within the adductor pool, and arrows indicate ectopic CNTFR $\alpha$-overexpressing MNs in presumptive sartorius and femerotibialis MNs. The white ellipse in the right panel encloses the LMC; medial is to the right. Hoechst-stained nuclei are blue in the right panel. Scale bar, $50 \mu \mathrm{m}$. 
A

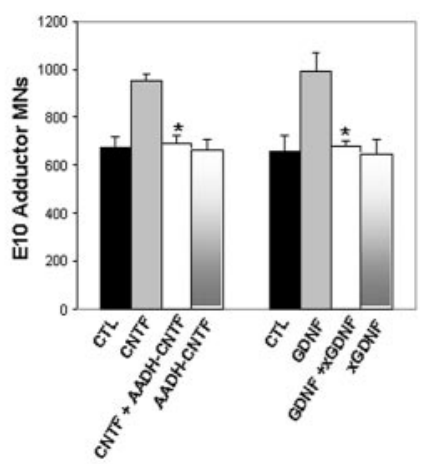

C

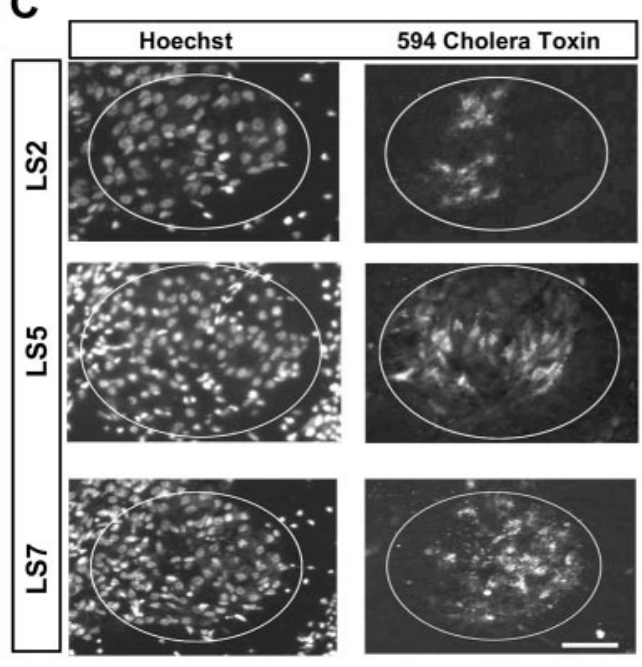

B

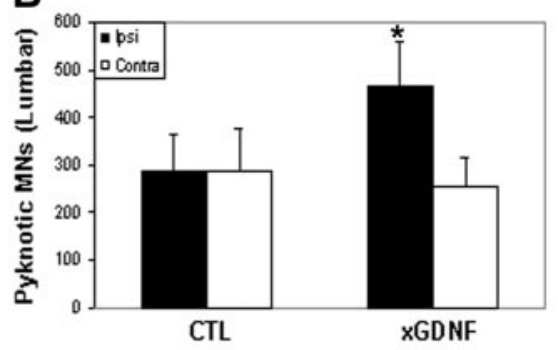

D

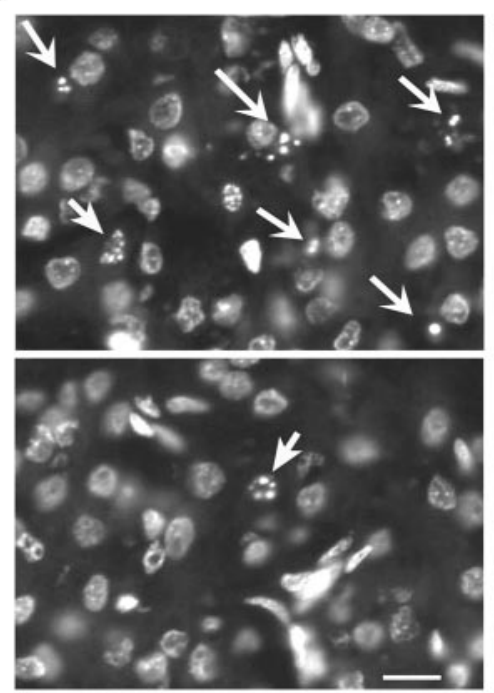

E

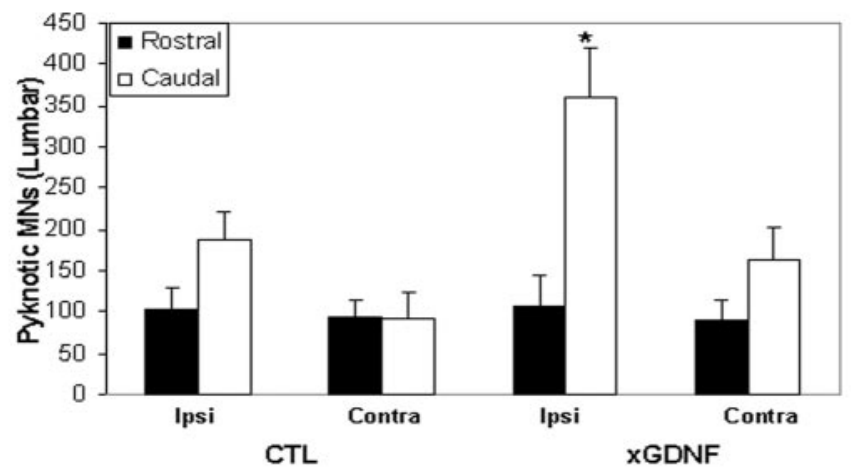

Figure 7. Neither CNTF nor GDNF signaling is necessary for adductor MN survival during the period of $\mathrm{PCD}$. A, Embryos were treated with control vehicle (CTL), CNTF (5 $\mu \mathrm{g}$, E6-E9), AADH-CNTF (100 $\mu \mathrm{g}$, E6-E9), AADH-CNTF together with CNTF, GDNF (5 $\mu \mathrm{g}, \mathrm{E} 6$-E9), neutralizing antibodies against human GDNF (anti-GDNF, $20 \mu \mathrm{g}$, E6 and E8), or anti-GDNF together with GDNF, and adductor MNs were retrogradely labeled at E10. Data in $A, B$, and $E$ represent the means $\pm S D ; n=4$ per group. ${ }^{*} p<0.05$ for AADH-CNTF + CNTF versus CNTF alone, or for anti-GDNF + GDNF versus GDNF alone; Student's t test. B, GDNF signaling is required for lumbar MN survival. Unilateral injections of $5 \mu \mathrm{g} / \mu$ l anti-GDNF (also containing $0.5 \mu \mathrm{g} / \mu \mathrm{l}$ Alexa-Fluor 594-conjugated cholera toxin $\beta$ ) were made into the hindlimb at $\mathrm{E}$, and pyknotic MNs were counted on Nissl-stained sections throughout the entire lumbar spinal cord at E8. Data represent the means \pm SD; $n=4$ for anti-GDNF, and $n=10$ for control, which included 5 $\mu \mathrm{g} / \mu \mathrm{llgG}$-treated, sham-operated, and windowed-only embryos. ${ }^{*} p<0.02$ for ipsilateral anti-GDNF-injected versus ipsilateral control; Student's $t$ test. C, The distribution of lumbar MNs exposed to anti-GDNF injections made into the hindlimb at E7 was measured by examining transverse sections through the lumbar spinal cord at E8 for Alexa-Fluor 594-conjugated cholera toxin $\beta$-positive cells. The ovals represent the LMC; medial is to the left. The adductor motor nucleus resides medially from lumbar (LS) $1-3$, which is retrogradely labeled after anti-GDNF hindlimb injection (top right). D, Hindlimb anti-GDNF injection (top) increases the number of dying lumbar MNs (white arrows) versus control in Hoechst-labeled transverse sections. $E$, Hindlimb anti-GDNF injection increases dying lumbar MNs only in the caudal half of the lumbar spinal cord. Counts of pyknotic MNs generated from $B$ were subdivided into rostral and caudal halves of the lumbar spinal cord. The caudal, but not rostral, lumbar spinal cord ipsilateral to the injection of anti-GDNF (ipsi) exhibits an increase in pyknotic MNs versus control ipsilateral caudal and rostral lumbar spinal cord, respectively. ${ }^{*} p<0.01$; Student's $t$ test. Scale bars: $C, 50 \mu \mathrm{m} ; D, 20 \mu \mathrm{m}$.

GFR $\alpha 1$ has been recently shown to physically interact with the neural cell adhesion molecule and mediate GDNF signals in the absence of cRet (Paratcha et al., 2003), we examined whether GFR $\alpha 1$-positive, cRetnegative MNs could be rescued from PCD by exogenous GDNF. Our results showed that at least for those MNs innervating the medial gastrocnemius muscle of the ventral shank, such signaling fails to prevent MNs from undergoing PCD. Thus, cRet expression by MNs is necessary for transducing the rescue effects of GDNF family members.

There are several reasons why GPIlinked receptor expression in the target may be unable to activate receptor tyrosine kinase activation in innervating MNs during the period of cell death. First, CNTFR $\alpha$ expression in the nerve, but not in the extracellular matrix of muscle, colocalizes with SV2-immunoreactive nerve terminals (data not shown), suggesting that fibroblast-derived CNTFR $\alpha$ is membrane bound or otherwise unavailable to contact axons. Second, cRet and TrkB are expressed in dendrites, cell body, and proximal nerve and are thus more accessible to nerve-derived than limb-derived GPIlinked receptors. Finally, non-muscle cells in the limb express cRet and muscle cells express LIFR $\beta /$ gp 130 mRNA during the period of MN cell death (Table 1) (Helgren et al., 1994). Thus, target-derived GPI-anchored NTF-R may be expressed in the limb for the purpose of activating tyrosine kinase-positive cells in the limb and not in MNs.

\section{GDNF and CNTF signaling are not} necessary for adductor $\mathrm{MN}$ survival Interference with GDNF and CNTFR activation potentiates the death of some MN populations (caudal lumbar $\mathrm{MNs}$ by GDNF) but fails to increase adductor MN cell death in vivo. Similarly, although the receptors for HGF and BDNF are expressed by the oculomotor nucleus, neither excess HGF nor BDNF rescue these MNs from PCD (Steljes et al., 1999; Caton et al., 2000; Novak et al., 2000). However, inhibition of other specific NTF signaling pathways does result in the increased death of some subsets of spinal MNs during the period of PCD (Garcés et al., 2000; Novak et al., 2000; Oppenheim et al., 2000, 2001; Forger et al., 2003).

For specific subpopulations of MNs, NTF-R signaling may mediate nonsurvival aspects of MN development before, during or after the cell death period (Henderson, 1996). For example, mice deficient in cRet appear to exhibit deficits in 
neuronal number before the onset of PCD (Enomoto et al., 2001; Oppenheim et al., 2002). Similarly, subpopulations of MNs in mice lacking cMet or GDNF fail to innervate their appropriate targets (Maina et al., 2001; Haase et al., 2002). Alternatively, it is possible that the absence of GDNF and CNTF receptor signaling is compensated by the activity of other NTF-Rs in adductor MNs, because both of these molecules signal through receptor tyrosine kinases shared by other trophic factor ligands (Stahl and Yancopoulos, 1994; Airaksinen and Saarma, 2002). However, mice deficient in several different individual NTFs or NTF-Rs exhibit profound MN losses by birth, suggesting that the function of these factors in survival is not always compensated by that of others. Ongoing experiments aimed at discerning the onset and subtype specificity of MN loss in various NTF mutants will address this issue. It will also be of considerable interest to examine NTF-R signal transduction in subtypes of MNs that are affected or not affected by trophic factor addition or inhibition in vivo.

\section{References}

Airaksinen MS, Saarma M (2002) The GDNF family: signaling, biological functions and therapeutic value. Nat Rev Neurosci 3:383-394.

Alexander WS, Rakar S, Robb L, Farley A, Willson TA, Zhang JG, Hartley L, Kikuchi Y, Kojima T, Nomura H, Hasegawa M, Maeda M, Fabri L, Jachno K, Nash A, Metcalf D, Nicola NA, Hilton DJ (1999) Suckling defect in mice lacking the soluble haemopoietin receptor NR6. Curr Biol 9:605-608.

Arce V, Pollock RA, Philippe JM, Pennica D, Henderson CE, deLapeyrière O (1998) Synergistic effects of Schwann- and muscle-derived factors on motoneuron survival involve GDNF and cardiotrophin-1 (CT-1). J Neurosci 18:1440-1448.

Baloh RH, Tansey MG, Golden JP, Creedon DJ, Heuckeroth RO, Keck CL, Zimonjic DB, Popescu NC, Johnson Jr EM, Milbrandt J (1997) TrnR2, a novel receptor that mediates neurturin and GDNF signaling through Ret. Neuron 18:793-802.

Bottaro DP, Rubin JS, Faletto DL, Chan AM, Kmiecik TE, Vande Woude GF, Aaronson SA (1991) Identification of the hepatocyte growth factor receptor as the c-met proto-oncogene product. Science 251:802-804.

Caton A, Hacker A, Naeem A, Livet J, Maina F, Bladt F, Klein R, Birchmeier C, Guthrie S (2000) The branchial arches and HGF are growth-promoting and chemoattractant for cranial motor axons. Development 127:1751-1766.

Clarke PG, Oppenheim RW (1995) Neuron death in vertebrate development: in vivo methods. Methods Cell Biol 46:277-321.

Dahm LM, Landmesser LT (1991) The regulation of synaptogenesis during normal development and following activity blockade. J Neurosci 11:238-255.

Davis S, Aldrich TH, Stahl N, Pan L, Taga T, Kishimoto T, Ip NY, Yancopoulos GD (1993) LIFR beta and gp130 as heterodimerizing signal transducers of the tripartite CNTF receptor. Science 260:1805-1808.

Di Marco A, Gloaguen I, Demartis A, Saggio I, Graziani R, Paonessa G, Laufer R (1996) Identification of ciliary neurotrophic factor (CNTF) residues essential for leukemia inhibitory factor receptor binding and generation of CNTF receptor antagonists. J Biol Chem 272:23069-23075.

Du K, Herzig S, Kulkarni RN, Montminy M (2003) TRB3: a tribbles homolog that inhibits $\mathrm{Akt} / \mathrm{PKB}$ activation by insulin in liver. Science 300:1574-1577.

Duong CV, Geissen M, Rohrer H (2002) The developmental expression of vasoactive intestinal peptide (VIP) in cholinergic sympathetic neurons depends on cytokines signaling through LIFRbeta-containing receptors. Development 129:1387-1396.

Ebens A, Brose K, Leonardo ED, Hanson Jr MG, Bladt F, Birchmeier C, Barres BA, Tessier-Lavigne M (1996) Hepatocyte growth factor/scatter factor is an axonal chemoattractant and a neurotrophic factor for spinal motor neurons. Neuron 17:1157-1172.

Elson GC, Lelievre E, Guillet C, Chevalier S, Plun-Favreau H, Froger J, Suard I, de Coignac AB, Delneste Y, Bonnefoy JY, Gauchat JF, Gascan H (2000) CLF associates with CLC to form a functional heteromeric ligand for the CNTF receptor complex. Nat Neurosci 3:867-872.

Enomoto H, Crawford PA, Gorodinsky A, Heuckeroth RO, Johnson Jr EM, Milbrandt J (2001) RET signaling is essential for migration, axonal growth and axon guidance of developing sympathetic neurons. Development 128:3963-3974.

Forger NG, Prevette D, deLapeyrière O, de Bovis B, Wang S, Bartlett P, Oppenheim RW (2003) Cardiotrophin-like cytokine/cytokine-like factor 1 is an essential trophic factor for lumbar and facial motoneurons in vivo. J Neurosci 26:8854-8858.

Furber S, Oppenheim RW, Prevette D (1987) Naturally occurring neuron death in the ciliary ganglion of the chick embryo following removal of preganglionic input: evidence for the role of afferents in ganglion cell survival. J Neurosci 7:1816-1832.

Garcés A, Haase G, Airaksinen MS, Livet J, Filippi P, deLapeyrière O (2000) GFRalpha 1 is required for development of distinct subpopulations of motoneuron. J Neurosci 20:4992-5000.

Garcés A, Livet J, Grillet N, Henderson CE, Delapeyrière O (2001) Responsiveness to neurturin of subpopulations of embryonic rat spinal motoneuron does not correlate with expression of GFR alpha 1 or GFR alpha 2. Dev Dyn 220:189-197.

Grieshammer U, Lewandoski M, Prevette D, Oppenheim RW, Martin GR (1998) Muscle-specific cell ablation conditional upon Cre-mediated DNA recombination in transgenic mice leads to massive spinal and cranial motoneuron loss. Dev Biol 197:234-247.

Haase G, Dessaud E, Garces A, de Bovis B, Birling M, Filippi P, Schmalbruch $\mathrm{H}$, Arber S, deLapeyrière O (2002) GDNF acts through PEA3 to regulate cell body positioning and muscle innervation of specific motor neuron pools. Neuron 35:893-905.

Hamburger V (1975) Cell death in the development of the lateral motor column of the chick embryo. J Comp Neurol 160:535-546.

Hamburger V, Hamilton HL (1951) A series of normal stages in the development of the chick embryo. J Morphol 88:49-92.

Hashino E, Shero M, Junghans D, Rohrer H, Milbrandt J, Johnson Jr EM (2001) GDNF and neurturin are target-derived factors essential for cranial parasympathetic neuron development. Development 128:3773-3782.

Helgren ME, Squinto SP, Davis HL, Parry DJ, Boulton TG, Heck CS, Zhu Y, Yancopoulos GD, Lindsay RM, DiStefano PS (1994) Trophic effect of ciliary neurotrophic factor on denervated skeletal muscle. Cell 76:493-504.

Heller S, Finn TP, Huber J, Nishi R, Geissen M, Puschel AW, Rohrer H (1995) Analysis of function and expression of the chick GPA receptor (GPAR alpha) suggests multiple roles in neuronal development. Development 121:2681-2693.

Henderson CE (1996) Role of neurotrophic factors in neuronal development. Curr Opin Neurobiol 6:64-70.

Hohn A, Leibrock J, Bailey K, Barde YA (1990) Identification and characterization of a novel member of the nerve growth factor/brain-derived neurotrophic factor family. Nature 344:339-341.

Hollyday M (1980) Organization of motor pools in the chick lumbar lateral motor column. J Comp Neurol 194:143-170.

Hollyday M, Hamburger V (1976) Reduction of the naturally occurring motor neuron loss by enlargement of the periphery. J Comp Neurol 170:311-320.

Homma S, Yaginuma H, Vinsant S, Seino M, Kawata M, Gould T, Shimada T, Kobayashi N, Oppenheim RW (2003) Differential expression of the GDNF family receptors RET and GFRalpha1, 2, and 4 in subsets of motoneurons: a relationship between motoneuron birthdate and receptor expression. J Comp Neurol 456:245-259.

Horton AR, Barlett PF, Pennica D, Davies AM (1998) Cytokines promote the survival of mouse cranial sensory neurones at different developmental stages. Eur J Neurosci 10:673-679.

Hughes RA, Sendtner M, Thoenen H (1993) Members of several gene families influence survival of rat motoneurons in vitro and in vivo. J Neurosci Res 36:663-671.

Ip NY, McClain J, Barrezueta NX, Aldrich TH, Pan L, Li Y, Wiegand SJ, Friedman B, Davis S, Yancopoulos GD (1993) The alpha component of the CNTF receptor is required for signaling and defines potential CNTF targets in the adult and during development. Neuron 10:89-102.

Janiga TA, Rind HB, von Bartheld CS (2000) Differential effects of the trophic factors BDNF, NT-4, GDNF, and IGF-I on the isthmo-optic nucleus in chick embryos. J Neurobiol 43:289-303.

Jing S, Wen D, Yu Y, Holst PL, Luo Y, Fang M, Tamir R, Antonio L, Hu Z, Cupples R, Louis JC, Hu S, Altrock BW, Fox GM (1996) GDNF-induced activation of the ret protein tyrosine kinase is mediated by GDNFR-alpha, a novel receptor for GDNF. Cell 85:1113-1124. 
Jones KR, Reichardt LF (1990) Molecular cloning of a human gene that is a member of the nerve growth factor family. Proc Natl Acad Sci USA 87:8060-8064.

Jungbluth S, Koentges G, Lumsden A (1997) Coordination of early neural tube development by BDNF/trkB. Development 124:1877-1885.

Kalcheim C, Carmeli C, Rosenthal A (1992) Neurotrophin 3 is a mitogen for cultured neural crest cells. Proc Natl Acad Sci USA 89:1661-1665.

Klein R, Nanduri V, Jing SA, Lamballe F, Tapley P, Bryant S, Cordon-Cardo C, Jones KR, Reichardt LF, Barbacid M (1991) The trkB tyrosine protein kinase is a receptor for brain-derived neurotrophic factor and neurotrophin-3. Cell 66:395-403.

Klein RD, Sherman D, Ho WH, Stone D, Bennett GL, Moffat B, Vandlen R, Simmons L, Gu Q, Hongo JA, Devaux B, Poulsen K, Armanini M, Nozaki C, Asai N, Goddard A, Phillips H, Henderson CE, Takahashi M, Rosenthal A (1997) A GPI-linked protein that interacts with Ret to form a candidate neurturin receptor. Nature 387:717-721.

Kotzbauer PT, Lampe PA, Heuckeroth RO, Golden JP, Creedon DJ, Johnson Jr EM, Milbrandt J (1996) Neurturin, a relative of glial-cell-line-derived neurotrophic factor. Nature 384:467-470.

Krieglstein K, Richter S, Farkas L, Schuster N, Dunker N, Oppenheim RW, Unsicker K (2000) Reduction of endogenous transforming growth factors beta prevents ontogenetic neuron death. Nat Neurosci 3:1085-1090.

Lamballe F, Klein R, Barbacid M (1991) trkC, a new member of the trk family of tyrosine protein kinases, is a receptor for neurotrophin-3. Cell 66:967-979.

Landmesser L (1978) The distribution of motoneurones supplying chick hindlimb muscles. J Physiol (Lond) 284:371-389.

Ledda F, Paratcha G, Ibanez CF (2002) Target-derived GFRalphal as an attractive guidance signal for developing sensory and sympathetic axons via activation of Cdk5. Neuron 36:387-401.

Leibrock J, Lottspeich F, Hohn A, Hofer M, Hengerer B, Masiakowski P, Thoenen H, Barde YA (1989) Molecular cloning and expression of brain-derived neurotrophic factor. Nature 341:149-152.

Lin JH, Saito T, Anderson DJ, Lance-Jones C, Jessell TM, Arber S (1998) Functionally related motor neuron pool and muscle sensory afferent subtypes defined by coordinate ETS gene expression. Cell 95:393-407.

MacLennan AJ, Neitzel KL, Devlin BK, Garcia J, Hauptman GA, Gloaguen I, Di Marco A, Laufer R, Lee N (2000) In vivo localization and characterization of functional ciliary neurotrophic factor receptors which utilize JAK-STAT signaling. Neuroscience 99:761-772.

Maina F, Pante G, Helmbacher F, Andres R, Porthin A, Davies AM, Ponzetto C, Klein R (2001) Coupling Met to specific pathways results in distinct developmental outcomes. Mol Cell 7:1293-1306.

Maisonpierre PC, Belluscio L, Squinto S, Ip NY, Furth ME, Lindsay RM, Yancopoulos GD (1990) Neurotrophin-3: a neurotrophic factor related to NGF and BDNF. Science 247:1446-1451.

Martin-Caraballo M, Dryer SE (2002) Glial cell line-derived neurotrophic factor and target-dependent regulation of large-conductance $\mathrm{K}(\mathrm{Ca})$ channels in developing chick lumbar motoneurons. J Neurosci 22:10201-10208.

Masure S, Cik M, Hoefnagel E, Nosrat CA, Van der Linden I, Scott R, Van Gompel P, Lesage AS, Verhasselt P, Ibanez CF, Gordon RD (2000) Mammalian GFRalpha -4, a divergent member of the GFRalpha family of coreceptors for glial cell line-derived neurotrophic factor family ligands, is a receptor for the neurotrophic factor persephin. J Biol Chem 275:39427-39434.

McKay SE, Garner A, Caldero J, Tucker RP, Large T, Oppenheim RW (1996) The expression of trkB and p75 and the role of BDNF in the developing neuromuscular system of the chick embryo. Development 122:715-724.

Mikaels A, Livet J, Westphal H, De Lapeyrière O, Ernfors P (2000) A dynamic regulation of GDNF-family receptors correlates with a specific trophic dependency of cranial motor neuron subpopulations during development. Eur J Neurosci 12:446-456.

Milbrandt J, de Sauvage FJ, Fahrner TJ, Baloh RH, Leitner ML, Tansey MG, Lampe PA, Heuckeroth RO, Kotzbauer PT, Simburger KS, Golden JP, Davies JA, Vejsada R, Kato AC, Hynes M, Sherman D, Nishimura M, Wang LC, Vandlen R, Moffat B, et al. (1998) Persephin, a novel neurotrophic factor related to GDNF and neurturin. Neuron 20:245-253.

Mu X, Silos-Santiago I, Carroll SL, Snider WD (1993) Neurotrophin receptor genes are expressed in distinct patterns in developing dorsal root ganglia. J Neurosci 13:4029-4041.

Nakamura T, Nishizawa T, Hagiya M, Seki T, Shimonishi M, Sugimura A,
Tashiro K, Shimizu S (1989) Molecular cloning and expression of human hepatocyte growth factor. Nature 342:440-443.

Naldini L, Vigna E, Narsimhan RP, Gaudino G, Zarnegar R, Michalopoulos GK, Comoglio PM (1991) Hepatocyte growth factor (HGF) stimulates the tyrosine kinase activity of the receptor encoded by the protooncogene c-MET. Oncogene 6:501-504.

Nguyen QT, Parsadanian AS, Snider WD, Lichtman JW (1998) Hyperinnervation of neuromuscular junctions caused by GDNF overexpression in muscle. Science 279:1725-1729.

Novak KD, Prevette D, Wang S, Gould TW, Oppenheim RW (2000) Hepatocyte growth factor/scatter factor is a neurotrophic survival factor for lumbar but not for other somatic motoneurons in the chick embryo. J Neurosci 20:326-337.

Okado N, Oppenheim RW (1984) Cell death of motoneurons in the chick embryo spinal cord. IX. The loss of motoneurons following removal of afferent inputs. J Neurosci 4:1639-1652.

Oppenheim RW (1996) Neurotrophic survival molecules for motoneurons: an embarrassment of riches. Neuron 17:195-197.

Oppenheim RW, Yin QW, Prevette D, Yan Q (1992) Brain-derived neurotrophic factor rescues developing avian motoneurons from cell death. Nature 360:755-757.

Oppenheim RW, Prevette D, Haverkamp LJ, Houenou L, Yin QW, McManaman J (1993) Biological studies of a putative avian muscle-derived neurotrophic factor that prevents naturally occurring motoneuron death in vivo. J Neurobiol 24:1065-1079.

Oppenheim RW, Houenou LJ, Parsadanian AS, Prevette D, Snider WD, Shen L (2000) Glial cell line-derived neurotrophic factor and developing mammalian motoneurons: regulation of programmed cell death among motoneuron subtypes. J Neurosci 20:5001-5011.

Oppenheim RW, Wiese S, Prevette D, Armanini M, Wang S, Houenou LJ, Holtmann B, Gotz R, Pennica D, Sendtner M (2001) Cardiotrophin-1, a muscle-derived cytokine, is required for the survival of subpopulations of developing motoneurons. J Neurosci 21:1283-1291.

Oppenheim RW, Prevette D, Gould TW, Enomoto H, Milbrandt J (2002) Neuronal development and survival in mice deficient in the RET tyrosine kinase receptor. Soc Neurosci Abstr 428.16.

Paratcha G, Ledda F, Baars L, Coulpier M, Besset V, Anders J, Scott R, Ibanez CF (2001) Released GFRalphal potentiates downstream signaling, neuronal survival, and differentiation via a novel mechanism of recruitment of c-Ret to lipid rafts. Neuron 29:171-184.

Paratcha G, Ledda F, Ibanez CF (2003) The neural cell adhesion molecule NCAM is an alternative signaling receptor for GDNF family ligands. Cell 113:867-879.

Peng HB, Yang JF, Dai Z, Lee CW, Hung HW, Feng ZH, Ko CP (2003) Differential effects of neurotrophins and Schwann cell-derived signals on neuronal survival/growth and synaptogenesis. J Neurosci 12:5050-5060.

Phelan KA, Hollyday M (1991) Embryonic development and survival of brachial motoneurons projecting to muscleless chick wings. J Comp Neurol 311:313-320.

Pittman R, Oppenheim RW (1979) Cell death of motoneurons in the chick embryo spinal cord. IV. Evidence that a functional neuromuscular interaction is involved in the regulation of naturally occurring cell death and the stabilization of synapses. J Comp Neurol 187:425-446.

Poteryaev D, Titievsky A, Sun YF, Thomas-Crusells J, Lindahl M, Billaud M, Arumae U, Saarma M (1999) GDNF triggers a novel ret-independent Src kinase family-coupled signaling via a GPI-linked GDNF receptor alpha1. FEBS Lett 463:63-66.

Price SR, De Marco Garcia NV, Ranscht B, Jessell TM (2002) Regulation of motor neuron pool sorting by differential expression of type II cadherins. Cell 109:205-216.

Raoul C, Henderson CE, Pettmann B (1999) Programmed cell death of embryonic motoneurons triggered through the Fas death receptor. J Cell Biol 147:1049-1062.

Rodriguez-Tebar A, Dechant G, Barde YA (1990) Binding of brain-derived neurotrophic factor to the nerve growth factor receptor. Neuron 4:487-492.

Sato N, Matsuda K, Sakuma C, Foster DN, Oppenheim RW, Yaginuma H (2002) Regulated gene expression in the chicken embryo by using replication-competent retroviral vectors. J Virol 76:1980-1985.

Schaeren-Wiemers N, Gerfin-Moser A (1993) A single protocol to detect transcripts of various types and expression levels in neural tissue and 
cultured cells: in situ hybridization using digoxigenin-labelled cRNA probes. Histochemistry 6:431-440.

Schroeter S, Tosney KW (1991) Spatial and temporal patterns of muscle cleavage in the chick thigh and their value as criteria for homology. Am J Anat 191:325-350.

Senaldi G, Varnum BC, Sarmiento U, Starnes C, Lile J, Scully S, Guo J, Elliott G, McNinch J, Shaklee CL, Freeman D, Manu F, Simonet WS, Boone T, Chang MS (1999) Novel neurotrophin-1/B cell-stimulating factor-3: a cytokine of the IL- 6 family. Proc Natl Acad Sci USA 96:11458-11463.

Sendtner M, Carroll P, Holtmann B, Hughes RA, Thoenen H (1994) Ciliary neurotrophic factor. J Neurobiol 25:1436-1453.

Squinto SP, Stitt TN, Aldrich TH, Davis S, Bianco SM, Radziejewski C, Glass DJ, Masiakowski P, Furth ME, Valenzuela DM, et al. (1991) trkB encodes a functional receptor for brain-derived neurotrophic factor and neurotrophin-3 but not nerve growth factor. Cell 65:885-893.

Stahl N, Yancopoulos GD (1994) The tripartite CNTF receptor complex: activation and signaling involves components shared with other cytokines. J Neurobiol 25:1454-1466.

Steljes TP, Kinoshita Y, Wheeler EF, Oppenheim RW, von Bartheld CS (1999) Neurotrophic factor regulation of developing avian oculomotor neurons: Differential effects of BDNF and GDNF. J Neurobiol 41:295-315.

Stoker M, Gherardi E, Perryman M, Gray J (1987) Scatter factor is a fibroblastderived modulator of epithelial cell mobility. Nature 327:239-242.

Thompson J, Doxakis E, Pinon LG, Strachan P, Buj-Bello A, Wyatt S, Buchman VL, Davies AM (1998) GFRalpha-4, a new GDNF family receptor. Mol Cell Neurosci 11:117-126.

Tosney KW, Landmesser LT (1985) Development of the major pathways for neurite outgrowth in the chick hindlimb. Dev Biol 109:193-214.

Tran KT, Rusu SD, Satish L, Wells A (2003) Aging-related attenuation of EGF receptor signaling is mediated in part by increased protein tyrosine phosphatase activity. Exp Cell Res 289:359-367.

Treanor JJ, Goodman L, de Sauvage F, Stone DM, Poulsen KT, Beck CD, Gray C, Armanini MP, Pollock RA, Hefti F, Phillips HS, Goddard A, Moore MW, Buj-Bello A, Davies AM, Asai N, Takahashi M, Vandlen R, Henderson CE, Rosenthal A (1996) Characterization of a multicomponent receptor for GDNF. Nature 382:80-83.

Trupp M, Arenas E, Fainzilber M, Nilsson AS, Sieber BA, Grigoriou M, Kilkenny C, Salazar-Grueso E, Pachnis V, Arumae U (1996) Functional receptor for GDNF encoded by the c-ret proto-oncogene. Nature 381:785-789.

Trupp M, Belluardo N, Funakoshi H, Ibanez CF (1997) Complementary and overlapping expression of glial cell line-derived neurotrophic factor (GDNF), c-ret proto-oncogene, and GDNF receptor- alpha indicates multiple mechanisms of trophic actions in the adult rat CNS. J Neurosci 17:3554-3567.

Trupp M, Scott R, Whittemore SR, Ibanez CF (1999) Ret-dependent and -independent mechanisms of glial cell line-derived neurotrophic factor signaling in neuronal cells. J Biol Chem 274:20885-20894.

Tucker KL, Meyer M, Barde YA (2001) Neurotrophins are required for nerve growth during development. Nat Neurosci 4:29-37.

Varon S, Manthorpe M, Adler R (1979) Cholinergic neuronotrophic factors: I. Survival, neurite outgrowth and choline acetyltransferase activity in monolayer cultures from chick embryo ciliary ganglia. Brain Res 173:29-45.

Vernon EM, Oppenheim RW, Johnson JE (2004) Distinct muscle targets do not vary in the developmental regulation of brain-derived neurotrophic receptor. J Comp Neurol 470:330-337.

von Bartheld CS, Kinoshita Y, Prevette D, Yin QW, Oppenheim RW, Bothwell M (1994) Positive and negative effects of neurotrophins on the isthmo-optic nucleus in chick embryos. Neuron 12:639-654.

von Bartheld CS, Byers MR, Williams R, Bothwell M (1996) Anterograde transport of neurotrophins and axodendritic transfer in the developing visual system. Nature 379:830-833.

Weidner KM, Sachs M, Birchmeier W (1993) The Met receptor tyrosine kinase transduces motility, proliferation, and morphogenic signals of scatter factor/hepatocyte growth factor in epithelial cells. J Cell Biol 121:145-154.

Xu J, Gingras KM, Bengston L, Di Marco A, Forger NG (2001) Blockade of endogenous neurotrophic factors prevents the androgenic rescue of rat spinal motoneurons. J Neurosci 21:4366-4372.

Yan Q, Elliott JL, Matheson C, Sun J, Zhang L, Mu X, Rex KL, Snider WD (1993) Influences of neurotrophins on mammalian motoneurons in vivo. J Neurobiol 24:1555-1577.

Yamamoto Y, Livet J, Pollock RA, Garces A, Arce V, deLapeyrière O, Henderson CE (1997) Hepatocyte growth factor (HGF/SF) is a muscle-derived survival factor for a subpopulation of embryonic motoneurons. Development 124:2903-2913.

Yu T, Scully S, Yu Y, Fox GM, Jing S, Zhou R (1998) Expression of GDNF family receptor components during development: implications in the mechanisms of interaction. J Neurosci 18:4684-4696.

Zimmerman LB, De Jesus-Escobar JM, Harland RM (1996) The Spemann organizer signal noggin binds and inactivates bone morphogenetic protein 4. Cell 86:599-606.

Zurn AD, Winkel L, Menoud A, Djabali K, Aebischer P (1996) Combined effects of GDNF, BDNF, and CNTF on motoneuron differentiation in vitro. J Neurosci Res 44:133-141. 